\title{
Estimation of biogenic volatile organic compound (BVOC) emissions from the terrestrial ecosystem in China using real-time remote sensing data
}

Estimation of BVOC emissions in China using MODIS data

M. Li et al.

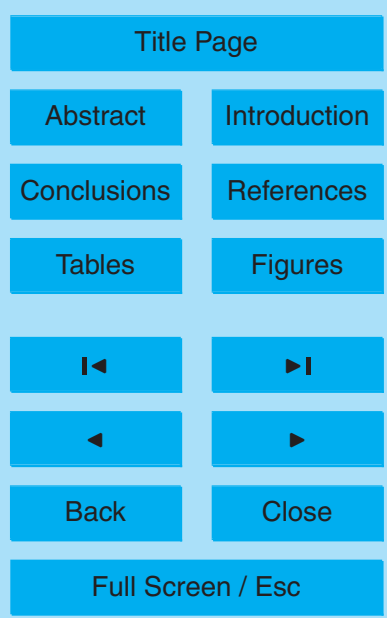

Published by Copernicus Publications on behalf of the European Geosciences Union. 


\section{Abstract}

Because of the high emission rate and reactivity, biogenic volatile organic compounds (BVOCs) play a significant role in the terrestrial ecosystems, human health, secondary pollution, global climate change and the global carbon cycle. Past estima5 tions of BVOC emissions in China were based on outdated algorithms and coarsely resolved meteorological data, and there have been significant inconsistences between the land surface parameters of dynamic models and those of BVOC estimation models, leading to large inaccuracies in the estimated results. To refine BVOC emission estimations for China and to further explore the role of BVOCs in the atmosphere, 10 we used the latest algorithms of MEGAN (Model of Emissions of Gases and Aerosols from Nature), with MM5 (the Fifth-Generation Mesoscale Model) providing highly resolved meteorological data, to estimate the biogenic emissions of isoprene $\left(\mathrm{C}_{5} \mathrm{H}_{8}\right)$ and seven monoterpene species $\left(\mathrm{C}_{10} \mathrm{H}_{16}\right)$ in 2006. Real-time MODIS (Moderate Resolution Imaging Spectroradiometer) data were introduced to update the land surface parameters and to improve the simulation performance of MM5, and to determine the influence of leaf area index (LAI) and leaf age deviation from standard conditions. In this study, the annual BVOC emissions for the whole country totaled $12.97 \mathrm{Tg}$ C, a relevant value compared with past studies. Therein, the most important individual contributor was isoprene $\left(9.36 \mathrm{TgC} \mathrm{yr}^{-1}\right)$, followed by $\alpha$-pinene $\left(1.24 \mathrm{TgC} \mathrm{yr}^{-1}\right.$ ) and $\beta$-pinene $20 \quad\left(0.84 \mathrm{TgC} \mathrm{yr}^{-1}\right)$. Due to the considerable regional disparity in plant distributions and meteorological conditions across China, BVOC emissions presented significant spatial and temporal variations. Spatially, isoprene emission was concentrated in South China, which is covered by large areas of broadleaf forests and shrubs. While Southeast China was the top-ranking contributor of monoterpenes, in which the dominant vegetation genera consist of evergreen coniferous forests. Temporally, BVOC emissions primarily occurred in July and August, with daily emissions peaking at about 13:00 14:00 h (Beijing Time, BJT). In this study, we present an improved estimation of BVOC emissions, which provides important information for further exploration of the role of BVOCs in atmospheric processes.

\section{Estimation of BVOC emissions in China using MODIS data}

M. Li et al.

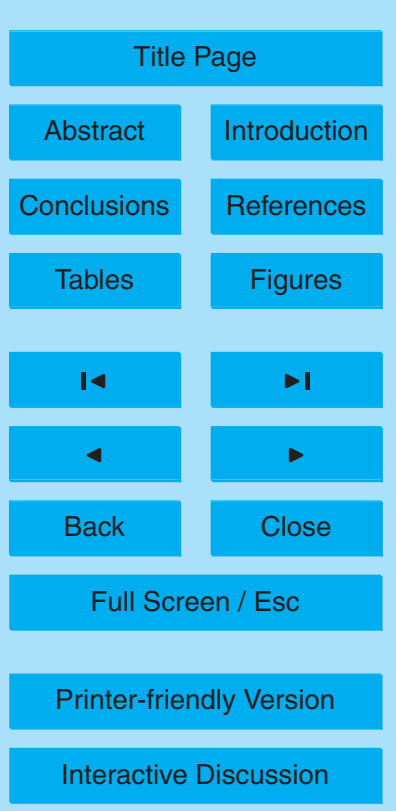




\section{Introduction}

Large quantities of non-methane volatile organic compounds (NMVOCs) are emitted from various anthropogenic and natural sources, such as vegetation, marine algae (McKay et al., 1996) and microbiological decomposition (Kuzma et al., 1995; Ze5 mankova and Brechler, 2010). On the global scale, natural emissions of NMVOCs equal or exceed anthropogenic emissions, nearly by an order of magnitude (Guenther et al., 1995; Benkovitz et al., 2004; Monks et al., 2009). On the regional scale, although anthropogenic sources usually dominate in urban areas, in many cases, BVOCs made significant contributions to the overall VOC inventories of both urban and rural areas 10 (Benjamin et al., 1997).

The importance of BVOCs was first acknowledged about $50 \mathrm{yr}$ ago (Went, 1960) and, compared with other abundant NMVOCs, is increased because of its key role in tropospheric physics and chemistry. First, BVOC emissions strongly influence the composition of the troposphere (Guenther et al., 1999; Monks et al., 2009). In particular, 15 isoprene and monoterpenes are thought to account for a major proportion of the total BVOC emissions (Kesselmeier and Staudt, 1999; Goldstein and Galbally, 2009; Monks et al., 2009). Second, many BVOC species are emitted in copious quantities and have extremely high reactivities with tropospheric oxidants. Through their oxidation, BVOCs can significantly affect the concentrations of ozone $\left(\mathrm{O}_{3}\right)$, hydroxyl radicals $(\mathrm{OH})$, nitrogen oxides $\left(\mathrm{NO}_{\mathrm{x}}\right)$ and so forth, consequently exerting a controlling influence on the oxidizing capacity of the atmosphere, and thus affecting local and global air quality (Ryerson et al., 2001; Wiedinmyer et al., 2004; Arneth et al., 2008; Goldstein and Galbally, 2009; Hallquist et al., 2009; Monks et al., 2009). Third, BVOCs, through complex oxidation processes, have also been implicated as key precursors to biogenic secondary organic aerosol (BSOA), thereby providing an additional source/burden of aerosol in the atmosphere and further exerting a strong influence on global climate-related issues (Griffin et al., 1999; Atkinson and Arey, 2003; Kanakidou et al., 2005; Szidat et al., 2006; Goldstein and Galbally, 2009; Hallquist et al., 2009; Pacifico et al., 2009;
ACPD

12, 6551-6592, 2012

\section{Estimation of BVOC emissions in China using MODIS data}

M. Li et al.

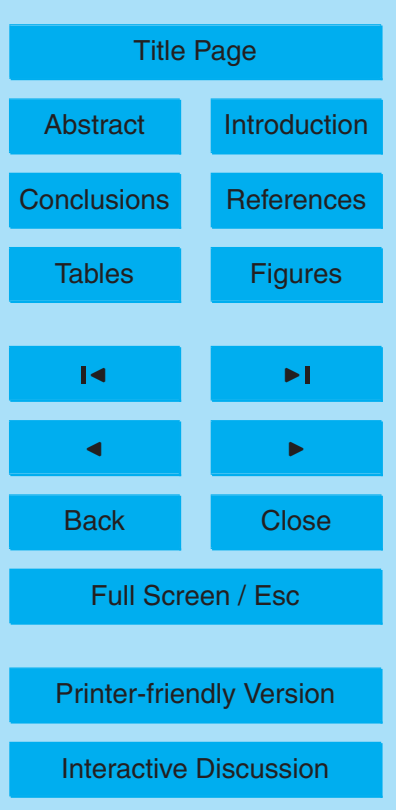


Perraud et al., 2011). Finally, many studies have also concluded that reactive BVOCs have significant implications for the global carbon (C) cycle of the ecosystem (Guenther, 2002; Kesselmeier et al., 2002; Streets et al., 2003; Kuhn et al., 2007; Karl et al., 2009).

5 To further explore the roles of BVOCs, it is essential to accurately estimate time- and space-resolved BVOC emissions. The most important emitter of BVOCs is vegetation, especially forest ecosystems (Zemankova and Brechler, 2010). China is a country that encompasses large areas, which are covered by a variety of plants, leading to remarkable temporal and spatial variations in BVOC emissions. In recent decades, 10 studies have been conducted in China focused on the development of national or regional BVOC emission inventories using various models or approaches, which reported an annual emission value of $4.06 \sim 15.00 \mathrm{TgC}$ for isoprene and $3.16 \sim 4.30 \mathrm{TgC}$ for monoterpenes on the national level (Guenther et al., 1995; Klinger et al., 2002; Wang et al., 2003; Tie et al., 2006; Wang et al., 2007; Leung et al., 2010; Zheng et al., 2010; 15 Wang et al., 2011).

However, past estimations were deficient with regard to estimation algorithms and input data. In terms of methodology, the estimation algorithms applied in these past studies did not fully consider the factors controlling BVOC emissions, such as LAI and leaf age. Some studies even unreasonably assumed the emissions of monoterpenes and other reactive VOCs to be solely temperature dependent, failing to recognize their dependence on light (Wang et al., 2003; Zheng et al., 2010). In addition, some estimates used outdated USGS (United States Geological Survey) land-cover data to identify vegetation distributions and/or to drive the dynamic meteorological model (Tie et al., 2006; Wang et al., 2011). The use of USGS data resulted in the misidentification of plant function types (PFTs) and large uncertainties in the simulated meteorological results, and potentially led to disagreements between the land surface parameters of the dynamic meteorological model and the BVOC estimation model. Many studies have explored the importance of land surface parameters in meteorological simulation (Molders, 2001; Atkinson, 2003) and have highlighted the potential of satellite data to

\section{ACPD}

12, 6551-6592, 2012

\section{Estimation of BVOC emissions in China using MODIS data}

M. Li et al.

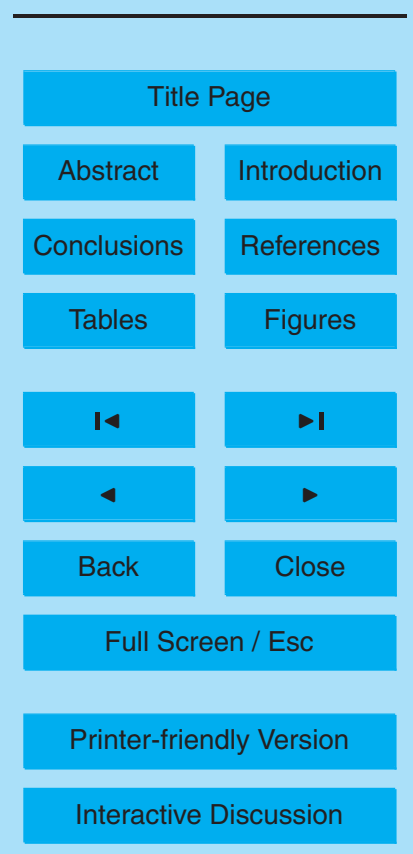


improve simulation performance in dynamical meteorological models (Gutman and Ignatov, 1998; Crawford et al., 2001; Kurkowski et al., 2003; de Foy et al., 2006; Yucel, 2006; Ge et al., 2008; Meng et al., 2009). Thirdly, many studies were based on coarsely resolved meteorological data interpolated from daily or monthly weather datasets, lead5 ing to coarse resolutions of emission inventories (for example $0.5^{\circ} \times 0.5^{\circ}$ in studies by Guenther et al., 1995) and failures to capture maximum emission values (Ashworth et al., 2010). Consequently, all the factors above jointly led to large uncertainties and great variations among the results of different studies.

In this work, we aimed to estimate the amounts, spatial distributions and temporal 10 providing hourly meteorological outputs to drive the estimations. Real-time MODIS data were introduced into MM5 to update the land surface parameters and improve the simulation performance, and were also used to provide a highly resolved input database for the calibration and estimation of BVOC emissions. Two primary classes of 15 BVOCs, isoprene $\left(\mathrm{C}_{5} \mathrm{H}_{8}\right)$ and monoterpenes $\left(\mathrm{C}_{10} \mathrm{H}_{16}\right)$, including a group of $\alpha$-pinene, $\beta$-pinene, limonene, myrcene, sabinene, 3-carene and ocimene, were considered in this study because of their substantial contributions to total BVOC emissions and their key role in atmospheric processes.

\section{Methods and data}

\subsection{Estimating BVOC emissions}

We estimated BVOC emissions based on the parameterized canopy environment emission activity (PCEEA) algorithms in MEGAN, described by Guenther et al. (2006) and Sakulyanontvittaya et al. (2008), as shown schematically in Fig. 1.

The net BVOC emission fluxes $\left(\mathrm{mg} \mathrm{m}^{-2} \mathrm{~h}^{-1}\right)$ into the above-canopy atmosphere

\section{ACPD}

12, 6551-6592, 2012

\section{Estimation of BVOC emissions in China using MODIS data}

M. Li et al.

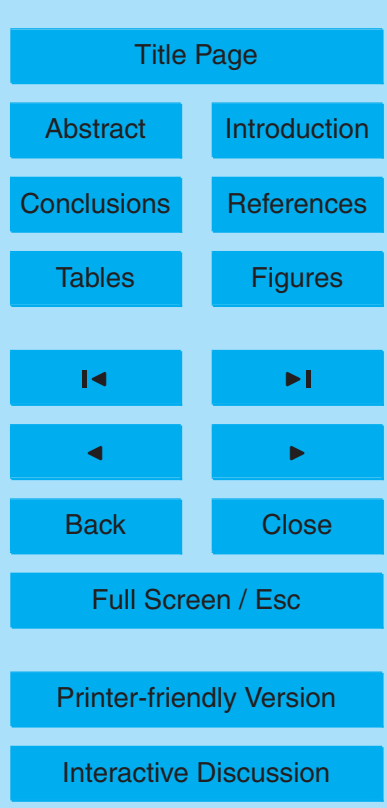

$$
\text { Emissions }=\mathrm{EF} \times \gamma_{T} \times\left[(1-\mathrm{LDF})+\mathrm{LDF} \times \gamma_{\mathrm{P}}\right] \times \gamma_{\mathrm{LAl}} \times \gamma_{\mathrm{age}} \times \gamma_{\mathrm{SM}} \times \rho
$$


where EF $\left(\mathrm{mg} \mathrm{m}^{-2} \mathrm{~h}^{-1}\right)$ is a standard canopy-scale emission factor, which represents the BVOC emission rates under standard conditions. Global gridded EFs for isoprene and seven monoterpene species, which have a base resolution of $30 \mathrm{~s}$ for the year 2000 based on measured tree species emission factors and global PFT distributions, 5 were downloaded from the CDP (Community Data Portal) website (available at http: //cdp.ucar.edu/).

Changes in BVOC emissions due to deviations from standard conditions were modified through a set of dimensionless emission activity factors $\left(\gamma_{T}, \gamma_{P}, \gamma_{\text {age }}, \gamma_{\mathrm{LAl}}, \gamma_{\mathrm{SM}}\right.$ and $\rho$ ). The light dependence of the BVOC emission processes was considered using the light-dependent function (LDF). Detailed information and calculation processes for all correction terms can be found in the published reports of Guenther et al. (2006) and Sakulyanontvittaya et al. (2008), so no further details are provided here.

In our estimations, the influences of soil moisture and detailed canopy information were neglected; thus, $\gamma_{\mathrm{SM}}$ and $\rho$, which represent the influence of soil moisture and production and loss of BVOCs within the canopy, respectively, were set to 1.

Highly resolved meteorological outputs of air temperatures at $2 \mathrm{~m}$ and solar shortwave radiations from MM5 were used to estimate the light and temperature dependencies $\left(\gamma_{T}\right.$ and $\left.\gamma_{P}\right)$ of BVOC emissions. The horizontal resolution of the modeling domain was $12 \mathrm{~km} \times 12 \mathrm{~km}$, centered at $\left(37.40^{\circ} \mathrm{N}, 102.52^{\circ} \mathrm{E}\right)$ with $440 \times 380$ cells in the horiof 2006, and each run covered 3.5 days with 12-h spin-up time.

The 8-day MODIS LAI data (MCD15A2), which have a $1 \mathrm{~km}$ resolution for the year 2006 and provides information regarding the seasonal evolution of vegetation characteristics (Justice et al., 2002), were used to estimate the influences of LAI $\left(\gamma_{\text {LAI }}\right)$ and
ACPD

12, 6551-6592, 2012

\section{Estimation of BVOC emissions in China using MODIS data}

M. Li et al.

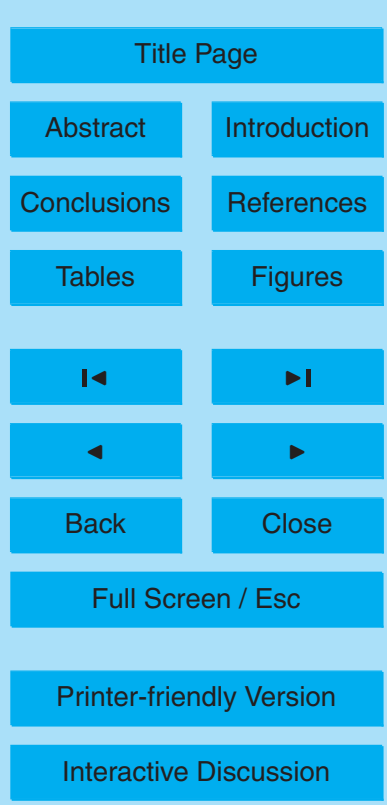




\subsection{Update of real-time MODIS data in MM5}

Accurate simulations of meteorological fields are important for the estimation of BVOC emissions. It is now widely recognized that several key land surface parameters, including land cover, vegetation fraction (VGF), soil temperature and moisture, significantly

5 affect land-atmosphere interactions and are thus important in weather simulations (Wittich and Hansing, 1995; Crawford et al., 2001; de Foy et al., 2006; Yucel, 2006).

By default, MM5 uses the USGS global $1 \mathrm{~km}$ land-use data derived from the AVHRR (Advanced Very High Resolution Radiometer) observation, which is based on 1-yr data from April 1992 to March 1993. The VGF data in MM5 are derived from monthly 10 AVHRR NDVI (Normalized Difference Vegetation Index) data at a coarse resolution of 10 min (de Foy et al., 2006; Meng et al., 2009).

However, over the last decade, global terrestrial ecosystems underwent great changes, such as urbanization, desertification and deforestation, causing the existing land-use data in MM5 to be outdated and, thus, likely to produce errors in weather sim15 ulations (Pielke et al., 2002; Yucel, 2006). By far, many studies have been conducted to update land surface data in meteorological models with satellite data (Crawford et al., 2001; Kurkowski et al., 2003; Tian et al., 2004; de Foy et al., 2006). Studies also reasoned that the global coverage, enhanced resolutions and accurate calibrations for retrievals of land surface parameters of MODIS enabled regional and global studies of biogeochemical cycles, land cover changes and so forth, for which AVHRR-based studies have limitations (Justice et al., 2002).

We introduced the latest MODIS land-use data and VGF data to replace the landsurface parameters in MM5. MODIS land-use data (MCD12Q1) for the year 2006 and water mask data (MOD44W) for the year 2000, which both have a resolution of $500 \mathrm{~m}$ (Justice et al., 2002), were used to obtain a new land-use map by mapping the 17 MODIS land-use categories defined by the International Geosphere-Biosphere Program $=($ IGBP $)$ onto the existing 24 USGS categories, as shown in Table 1. To validate the accuracy of the MODIS land-use data, the 1:100, 0000 plant distribution map
ACPD

12, 6551-6592, 2012

Estimation of BVOC emissions in China using MODIS data

M. Li et al.

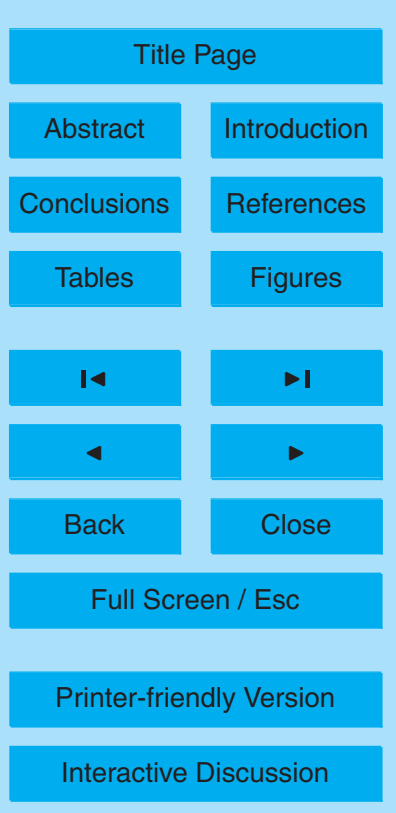


(Fig. 2c), which is based on local field surveys from the Plant Research Institute of the Chinese Academy of Sciences, was used for comparison. The land-use distribution in China changed dramatically over the past decade, as shown by Fig. 2. For example, according to the USGS data, South China was mainly covered by large areas of 5 crops (Fig. 2a), while, according to MODIS observations, South China contained mixed forest, grass and shrubs (Fig. 2b). For plant distributions obtained from field investigations, it demonstrated similar distribution patterns with those of the MODIS data. Therefore, we concluded that the MODIS land-use data better reflects the present land cover characteristics of China and may help to improve the simulations.

10 In this study, the VGF in MM5 was calculated from MODIS NDVI data (MOD13A2), giving monthly NDVI at $1 \mathrm{~km}$ resolution (Justice et al., 2002). Previous studies indicated linear (Wittich and Hansing, 1995; Gutman and Ignatov, 1998; de Foy et al., 2006) or nonlinear relationships (Purevdorj et al., 1998; Jakubauskas et al., 2000; Jiang et al., 2010) between NDVI and VGF. Here, we derived the value of VGF based on Eqs. (2) and (3), as recommended by (B. de Foy, private correspondence, 2007).

$$
\begin{array}{ll}
\mathrm{VGF}=1.5 \times(\mathrm{NDVI}-0.1) & (\mathrm{NDVI}<0.547) \\
\mathrm{VGF}=3.2 \times \mathrm{NDVI}-1.08 & (\mathrm{NDVI}<0.547)
\end{array}
$$

\section{Results and discussions}

\subsection{BVOC emission budgets}

20 Hourly emissions of isoprene and seven monoterpene species in China were calculated for the year 2006, with a spatial resolution of $12 \mathrm{~km} \times 12 \mathrm{~km}$. In the following section, all the results were measured as carbon weights of the constituent compounds, unless stated otherwise.

Seasonal and annual total emission budgets determined by this study are listed in
Table 2. As shown, the annual BVOC emissions totaled $12.97 \mathrm{Tg} C$ (which equals
$12,6551-6592,2012$

\section{Estimation of BVOC emissions in China using MODIS data}

M. Li et al.

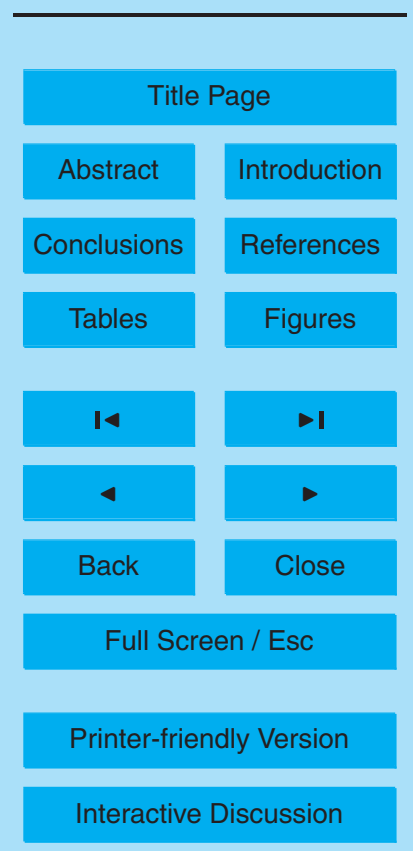

Interactive Discussion 
14.70 Tg compound). Regarding the relative contributions of individual species, the dominant contributor was isoprene, which had an annual emission budget of $9.36 \mathrm{Tg} \mathrm{C}$, accounting for approximately $71.6 \%$ of the total BVOC budget. The next most predominant contributor was $\alpha$-pinene $\left(1.24 \mathrm{Tg} \mathrm{Cyr}^{-1}\right)$, which was responsible for $9.8 \%$ of 5 the total BVOC emissions and $34.3 \%$ of the total monoterpene emissions, followed by $\beta$-pinene $\left(0.81 \mathrm{TgC} \mathrm{yr}^{-1}\right)$ and 3 -carene $\left(0.67 \mathrm{TgC} \mathrm{yr}^{-1}\right)$. The other four monoterpene species were less significant, and the annual emission budgets on the national scale were as follows: ocimene $(0.32 \mathrm{Tg} \mathrm{C})$, limonene $(0.28 \mathrm{Tg} \mathrm{C})$, sabinene $(0.18 \mathrm{Tg} \mathrm{C})$ and myrcene $(0.11 \mathrm{TgC})$. Overall, the annual emission budget of monoterpenes was $10 \quad 3.61 \mathrm{Tg}$ C, contributing approximately $28.4 \%$ to estimated BVOC emissions. According to our estimations, the annual total emission budget of isoprene was approximately 2.5 times that of the monoterpenes.

Because of the distinct reactivities of BVOC species, the better understanding of the relative contributions of individual BVOC species may be essential for the further explo-

oxidant control strategies (Hoffmann et a., 1997; Wiedinmyer et al, 2004; Hallquist et al., 2009).

\subsection{Spatial distributions of BVOC emission fluxes}

Because of the complex plant distributions (Fig. 2) and the wide range of meteorological variations across China, BVOC emissions showed considerable spatial variations. As described in Sect. 2.1, the spatial distribution of BVOC emission fluxes (expressed as the total emission of BVOCs per unit area per unit time) depended on the distribution of standard EFs, LAl as well as meteorological conditions.

The field measurements of previous studies indicated that broadleaf forests (espe25

cially Quercus, Populus and Eucalyptus) and shrubs were of high isoprene emission capacities, while an intense emission of monoterpenes generally corresponded to the dense distribution of coniferous forests (especially Pinus and Picea). Crops and grass were considered to have low isoprene emitting capacities or to emit no isoprene what-
12, 6551-6592, 2012

\section{Estimation of BVOC emissions in China using MODIS data}

M. Li et al.

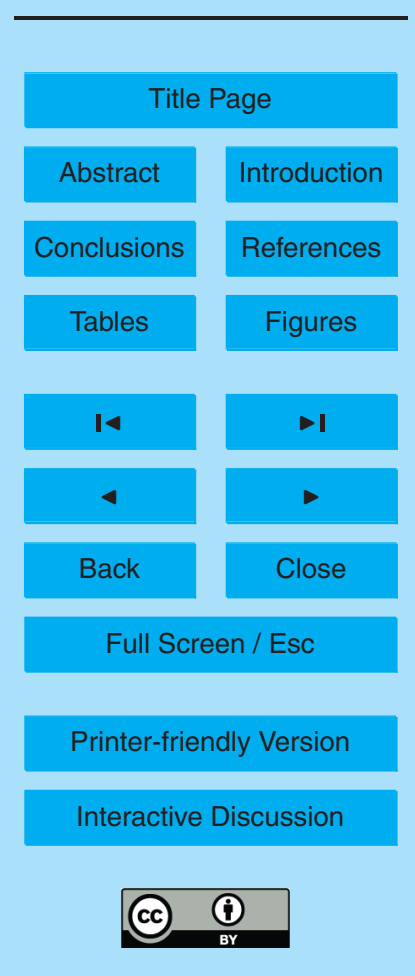


soever (Kesselmeier and Staudt, 1999; Wang et al., 2003; Guenther et al., 2006; Wang et al., 2007, 2011; Sakulyanontvittaya et al., 2008; Karl et al., 2009; Zheng et al., 2010). Thus, the types and magnitudes of BVOC emission fluxes were controlled by the amounts and compositions of plant species.

5 As shown in Fig. 2, forests and shrubs were mainly distributed in Northeast and South China. According to the survey results from the Plant Research Institute, Northeast China was primarily covered by deciduous coniferous forests (mainly Larix gmelini) and deciduous broadleaf forests (mainly Quercus mongolica, Tilia Mongolia and Betula platyphylla). By comparison, the distribution pattern of tree species in 10 South China was more complex. Large areas of evergreen coniferous forests (mainly Pinus massoniana and Cunninghamia lanceolata) and shrubs were found in Southeast China, while the main plant genera in Southwest China were larger groups of evergreen tree species, including evergreen broadleaf forests (e.g. Quercus aquifolioides), evergreen coniferous forests (Picea likiangensis var.balfouriana, Pinus yunnanensis and

Keteleeria evelyniana Mast) and shrubs. Notably, large areas of tropical rain forests were concentrated in the southeast of Tibet and south of Yunnan Province. Additionally, high fractional cover of deciduous broadleaf forests (mainly Quercus variabilis and Quercus liaotungensis) was found south of Shaanxi.

Correspondingly, the spatial distributions of standard emission factors for isoprene 20 and monoterpenes, presented in Fig. 3 (in which blank areas represent districts that had no plant cover), were consistent with the plant distributions in China (Fig. 2). On the whole, BVOC emission hotspots mainly occurred in the northeast and south of China. Specifically, plants in the northeast and south of China as well as in the south of Shaanxi exhibited high isoprene emission capacities (Fig. 3a). High monoterpene emission capacities were found in the northeast and southeast of China as well as the Sichuan-Tibet area (Fig. 3b).

\section{ACPD}

12, 6551-6592, 2012

\section{Estimation of BVOC emissions in China using MODIS data}

M. Li et al.

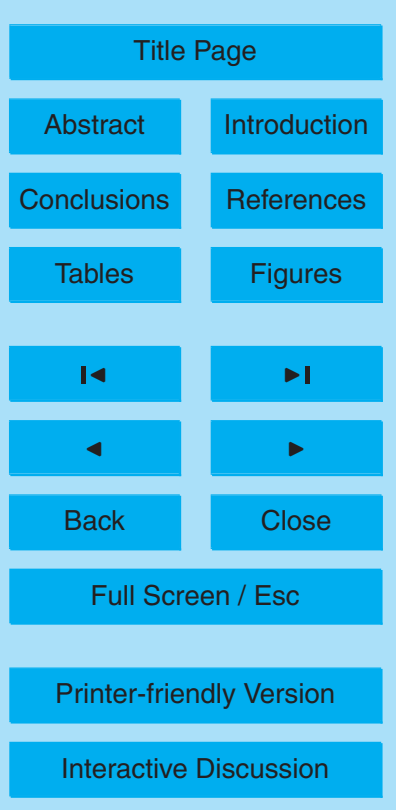


As illustrated in Fig. 4, the distribution patterns of biogenic emissions modified by real conditions agreed well with those under standard conditions (Fig. 3). The high EFs as well as the low latitude and resulting high temperature in the south of China led to strong isoprene emission there (Fig. 4a). High isoprene emission flux values were 5 also found in the south of Shaanxi. Although the emission capacities of the plants in the northeast of China were extremely high (Fig. 3a), the real emission flux values were relatively low (Fig. 4a). This result is because the high latitude of Northeast China led to a relative low temperature throughout the year. Additionally, as mentioned above, Northeast China was mainly covered by deciduous forests that cease to grow and nearly emit no isoprene in winter. High monoterpene emission flux values were centered in the south (especially the southeast) of China, where a high density of coniferous forests were concentrated (Fig. 2c). In Southwest China, especially the Sichuan-Tibet area, the high altitude and resulting low temperature of the Tibetan Plateau led to relatively low emission flux.

15 The lowest BVOC emissions occurred in Northwest China (Fig. 4), which is primarily covered by barren land and low emitting grass (Fig. 2). In North China and the north of East China region, which is mainly covered by crops (Fig. 2), BVOC emissions were also low (Fig. 4).

\subsection{Province-specific emission}

20 Each province's relative emission contribution depended on plant distribution, forested area, climatic conditions, and so forth. Detailed information depicting plant cover by province, listed in Table S1, was based on tree species data from the Chinese Academy of Sciences.

According to the estimated seasonal and annual BVOC emission budgets for 33 25 est emissions concentrated in the southern provinces of China. The top-ranking isoprene contributor was Yunnan, with approximately $0.86 \mathrm{TgC}$ emitted yearly, followed by Hunan $\left(0.72 \mathrm{TgC} \mathrm{yr}^{-1}\right)$ and Sichuan $\left(0.64 \mathrm{TgC} \mathrm{yr}^{-1}\right)$. The three provinces

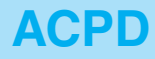

12, 6551-6592, 2012

\section{Estimation of BVOC emissions in China using MODIS data}

M. Li et al.

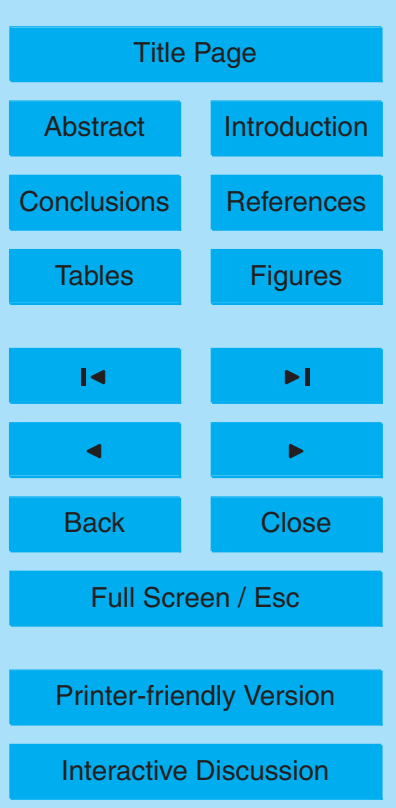


respectively contributed $9.5 \%, 7.9 \%$ and $7.0 \%$ to the total isoprene emission. The three provinces all had dense plant cover. For example, Yunnan Province had approximately $11.0 \times 10^{4} \mathrm{~km}^{2}$ of forests, accounting for $28.7 \%$ of its land area (Table S1). Subtropical evergreen broadleaf forests were also common in Yunnan, accounting for

5 approximately $28.2 \%\left(3.1 \times 10^{4} \mathrm{~km}^{2}\right)$ of the forested area. Moreover, Yunnan was also covered by large areas of shrubs $\left(8.6 \times 10^{4} \mathrm{~km}^{2}\right)$ (Table S1). The high isoprene emission capacities of broadleaf forests and shrubs led to the strong emission of isoprene in Yunnan. However, our results also depicted a contradiction between the extremely high forest and shrub coverage $\left(30.1 \times 10^{3}, \mathrm{~km}^{2}\right.$ of broadleaf forests and $108.4 \times 10^{3} \mathrm{~km}^{2}$ of 10 shrubs) and the relatively low isoprene contribution in Sichuan Province. As mentioned above, this phenomenon could result from the low temperatures (due to terrain height) in the west of Sichuan and the low solar radiation in the east of Sichuan, combined with the enclosed terrain and the abundant cloudiness in the atmosphere (Fig. 5).

The emission rates of monoterpenes were in general agreement with the distribu15 tion of coniferous forests. Specifically, Guangxi Province was the highest emitter, with an annual emission budget of $0.36 \mathrm{TgC}$ (contributing $9.9 \%$ to the annual emission of monoterpenes), followed by Yunnan (0.35 $\mathrm{Tg} \mathrm{C} \mathrm{yr}^{-1}, 9.8 \%$ ) and Hunan $\left(0.29 \mathrm{Tg} \mathrm{C} \mathrm{yr}^{-1}\right.$, $8.1 \%$ ) (Table 3). Coniferous forests were extensively distributed in these regions. For example, Guangxi was covered by $5.0 \times 10^{4} \mathrm{~km}^{2}$ of coniferous forests, mainly Pinus massoniana, accounting for $72.5 \%$ of the forested area of Guangxi $\left(6.9 \times 10^{4} \mathrm{~km}^{2}\right)$.

In determining regional environmental strategies, estimating province-specific BVOC emissions can provide constructive information for local administrations to make effective environmental decisions associated with oxidant control strategies, large-scale tree planting and urban greening programs (Schell et al., 2001; Liao et al., 2007; Leung et 25 al., 2010).

\subsection{Temporal variations in BVOC emissions}

There is increasing evidence that the seasonal changes of meteorological conditions and plant phenology greatly affect fluctuations in BVOC emission. Thus, seasonal

\section{Estimation of BVOC emissions in China using MODIS data}

M. Li et al.

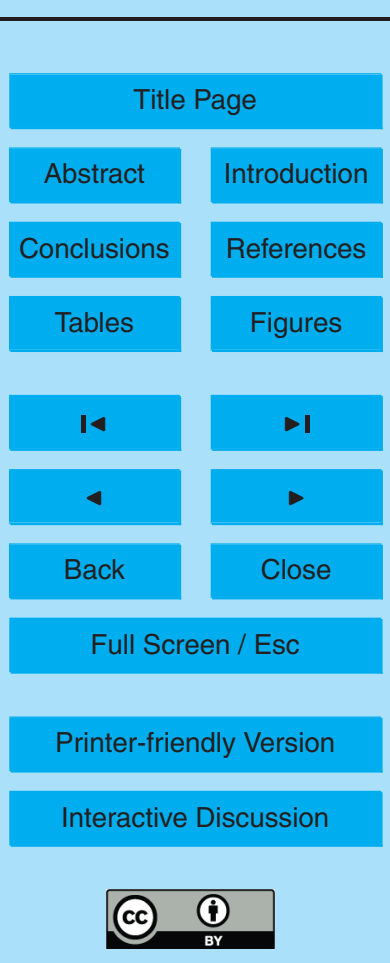


variabilities must be considered to achieve an accurate estimation of vegetative BVOC emissions.

Corresponding to the seasonal variations of LAI, temperature and solar radiation (Fig. 5), the distributions of isoprene (Fig. 6) and monoterpene (Fig. 7) emission fluxes 5 showed considerable seasonal variations.

Isoprene emissions were highest throughout the country in the summer and there were fewer spatial differences in emission distributions, consistent with the high temperatures, the high solar radiation, and the vigorous growth of forests, resulting in the high LAI values across China (Fig. 5). In winter, the LAI values decreased dramatically 10 with the loss of leaves in deciduous forests, particularly in Northeast China, where temperate deciduous forest dominated. By comparison, in the southeast and southwest of China, the LAI values remained high throughout the year because of the prevalence of tropical and subtropical evergreen forests (Fig. 5a). However, the low temperatures and low solar radiation in winter (Fig. 5) still led to low BVOC emissions across China 15 (Fig. 6d). In spring and autumn, the distribution pattern of isoprene emissions were similar and concentrated in the south of China (Fig. 6a and C), partly because of the relatively dense vegetation cover in South China. The distribution pattern of temperature, which decreasing from the south to the north and from the east to the west, and decreasing solar radiation from the northwest to the southeast (Fig. $5 b$ and c) could also lead to the dense distribution of isoprene in South China.

The spatial distribution patterns and seasonal variations of monoterpene emissions (Fig. 7) were similar to those of isoprene emissions, but the magnitudes of the former were much smaller and the spatial variations were larger. In addition, the distribution of monoterpene emissions were more centered in Southeast China (Fig. 7), where the density of coniferous forests was higher (Fig. 3).

Figure 8 shows the bell-shaped monthly evolution patterns of the total BVOC on a national level as well as the monthly changes of LAI, temperature and solar radiation. Marked differences in BVOC emissions were observed from month to month, which generally agreed with LAI, temperature and solar radiation trends. BVOC emissions

\section{Estimation of BVOC emissions in China using MODIS data}

M. Li et al.

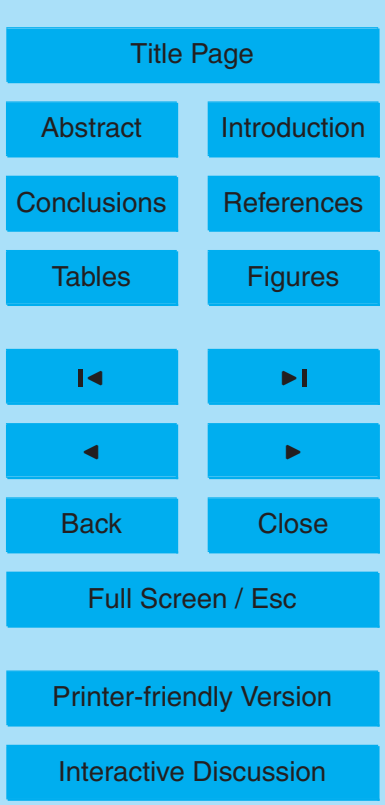


concentrated from April to October and peaked at $3.17 \mathrm{TgC}$ in July and August (Table 2). As the season transitioned with accompanying decreases in temperature, radiation and vegetation, BVOC emission intensities declined dramatically, reaching a lowest value of $0.11 \mathrm{TgC}$ in January (Table 2). Thus, monthly isoprene emissions fluctuated 5 between a maximum (2.41 Tg C) in July and August and a minimum $(0.05 \mathrm{Tg}$ C) in January. The same pattern was observed for monoterpene emissions, for which a peak emission of $0.76 \mathrm{TgC}$ occurred in July and the lowest emission $(0.05 \mathrm{TgC})$ occurred in February. Notably, the seasonal variability of monoterpenes was not as obvious as that of isoprene. The ratio of monoterpenes emitted in summer $(2.04 \mathrm{Tg} \mathrm{C})$ to that in o winter $(0.17 \mathrm{TgC})$ was approximately 12.0 , much smaller than the value (32.9) for isoprene $(6.25 \mathrm{TgC}$ in summer and $0.19 \mathrm{TgC}$ in winter), an observation that is attributed to the lack of light dependence of monoterpene emission and the strong temperature dependence of isoprene emission (Tie et al., 2006).

In addition to seasonal changes, the temporal patterns of BVOC emissions displayed 15 obvious diurnal cycles, which were primarily determined by diurnal variations in temperature and solar radiation. Biogenic isoprene emissions peaked at approximately 13:00 (BJT) and were lowest at night. During the night, because of the absence of solar radiation and isoprene's strong light-dependence, emissions of isoprene nearly ceased. In general, the diurnal pattern of monoterpene emissions agreed with that of isoprene, with the strongest emission of the former occurring at about 14:00 (BJT). By comparison, the diurnal variation observed for monoterpene emissions was much smaller than isoprene emissions. In addition, the monoterpene emissions maintained high levels during the night. According to previous studies of the oxidation mechanisms of BVOCs, isoprene oxidation is dominated by reactions with hydroxyl $(\mathrm{OH})$ during the day and reactions with nitrate radicals $\left(\mathrm{NO}_{3}\right)$ during the night, while ozone $\left(\mathrm{O}_{3}\right)$ plays a minor role at all times (Atkinson and Arey, 2003; Monks et al., 2009). Thus, the strong diurnal cycles of BVOCs have important effects on the formations and diurnal variations of ozone and SOA.

\section{ACPD}

$12,6551-6592,2012$

\section{Estimation of BVOC emissions in China using MODIS data}

M. Li et al.

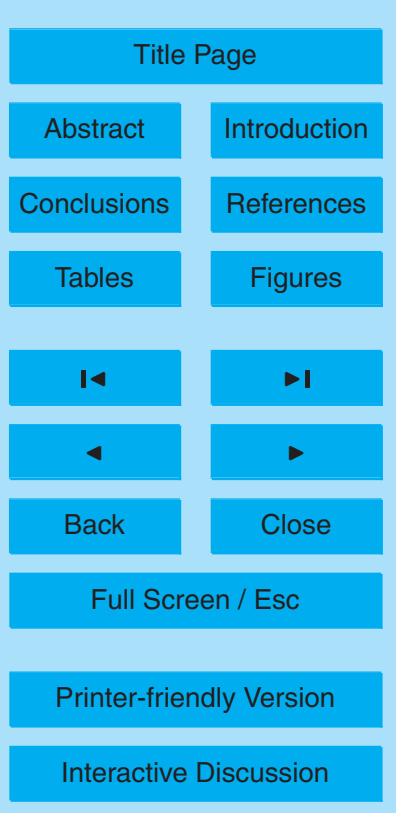




\subsection{Comparisons to anthropogenic emissions}

Recent studies proposed a link between BVOCs and AVOCs (anthropogenic volatile organic compounds), implying an interaction between them in the formation of SOA (Goldstein and Galbally, 2009). More important, because of the significant differences

5 in the composition, reactivity and oxidation products, the regional variation of relative weights for BVOCs compared with AVOCs could affect local air quality and pollution controlling strategies (Lane and Pandis, 2007). Therefore, to further explore the role of BVOCs in atmospheric chemical processes, it is essential to compare BVOC emissions to anthropogenic emissions.

10 The inventory of AVOC emissions in 2006 was taken from the study by Zhang et al. (2009), which gave AVOC emissions for all the major anthropogenic sources (power, industry, residential and transportation) in China. In total, approximately 23.2 Tg NMVOCs (measured as full molecular weights of the constituent compounds) were emitted from China in 2006 (Zhang et al., 2009). This value is approximately

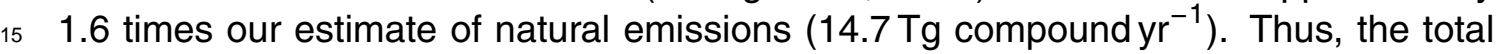
emission of NMVOCs was 37.94 Tg on the annual scale for the base year 2006, of which Guangdong made the largest contribution with an annual emission of $2.62 \mathrm{Tg}$, followed by Sichuan (2.32 $\mathrm{Tg} \mathrm{yr}^{-1}$ ) and Shandong $\left(2.20 \mathrm{Tg} \mathrm{yr}^{-1}\right.$ ). However, because of the complex plant distribution and economic structure across China, the relative ratio of BVOCs/AVOCs varied greatly by region.

The total amount of VOC emissions from natural and anthropogenic sources for each province is listed in Table 3. The distribution of anthropogenic NMVOC emissions was closely related to energy-consuming activities and population density, and reached a high value in the eastern area of China, while the distribution of BVOCs 25 was closely dependent on plant distribution and centered in the south and northeast of China. Of the 32 provinces for which complete data were listed (the anthropogenic NMVOCs emission data of Taiwan was not available), BVOC emissions were comparable to anthropogenic emissions (the difference of the two sources was less than $0.02 \mathrm{Tg}$
ACPD

12, 6551-6592, 2012

\section{Estimation of BVOC emissions in China using MODIS data}

M. Li et al.

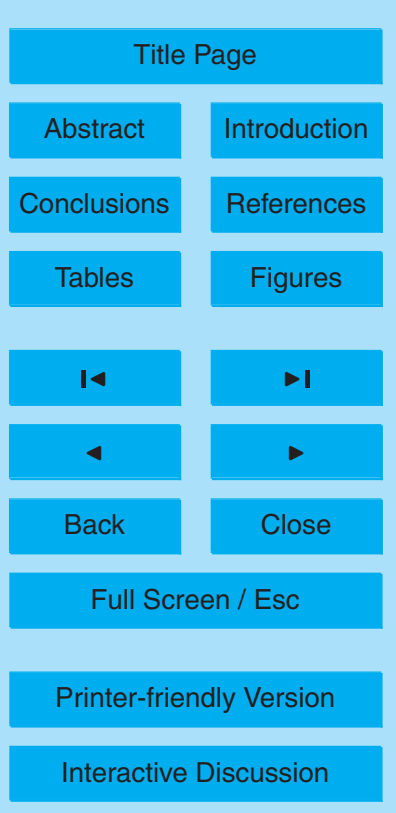


compound $\mathrm{yr}^{-1}$ ) in Chongqing, Guizhou and Heilongjiang. Emissions of NMVOCs from natural or anthropogenic origins in western provinces, which were undeveloped and sparsely populated (e.g., Qinghai and Tibet), all maintained a negligible value. On the other hand, in the other eight provinces (including Fujian, Guangxi, Hainan, Hunan,

5 Inner Mongolia, Jiangxi, Shaanxi, and Yunnan), where the plant cover fractions were high, BVOC emissions predominated over anthropogenic NMVOC emissions (Table 3), making it likely that BVOCs would play a more important role in local photochemistry processes and should not be ignored.

\subsection{Comparisons with other studies}

10 Because the algorithms and data applied in this work represent the latest findings on BVOC emissions, our results may differ greatly from previous published studies and it's important to compare the results for further improvement.

The results of this study were comparable with that of previous studies (Table 4), hence, our results were assumed to be reasonable. As shown in Table 4, the annual emission budgets estimated by the present study fall between the values given by Klinger et al. (2002) and Guenther et al. (1995). In addition, the spatial results of Klinger et al. (2002) indicate a higher BVOC emission in northern China than our value. This discrepancy is likely due to differences in model input values for the BVOC emission factors and estimation algorithms, because the two studies were both based on the outdated G95 algorithms (Guenther et al., 1995).

The results of this study are comparable (though slightly higher) with the recent study of Tie et al. (2006). Compared with the results of Tie et al. (2006), which are based on the algorithms of Guenther et al. (2000), our annual isoprene and monoterpene emissions were higher by $22 \%$ and $14 \%$, respectively. However, Tie et al. (2006) used USGS data to represent the land-cover distribution and did not account for the influences of LAI and leaf age, which may certainly explain the difference between our study and theirs. The differences between the two works may also be explained, in part,

\section{ACPD}

$12,6551-6592,2012$

\section{Estimation of BVOC emissions in China using MODIS data}

M. Li et al.

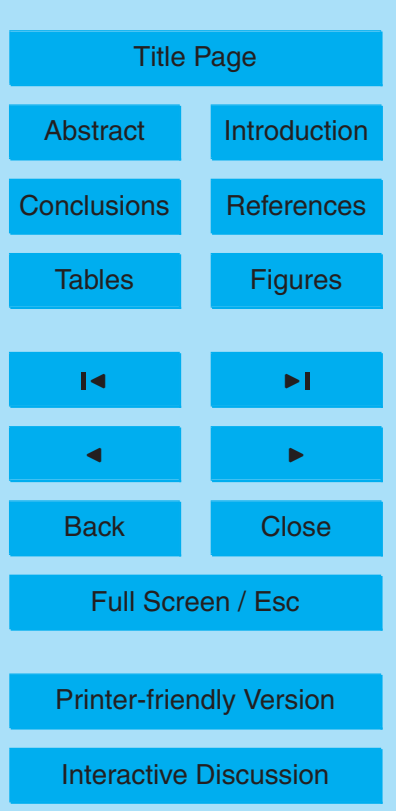


by the different meteorological simulation outputs given by WRF (Weather Research and Forecasting) in Tie et al. (2006) and by MM5 in our study.

To further evaluate China's BVOC emission capacity, we calculated the average BVOC emission flux from the total emission budget and land area. Comparing our 5 estimated emission fluxes with previous regional estimations for Beijing (Guenther et al., 1995; Klinger et al., 2002; Wang et al., 2003), PRD (Pearl River Delta) (Zheng et al., 2010; Wang et al., 2011) and Hong Kong (Tsui et al., 2009; Leung et al., 2010), it is clear that the estimated average emission flux for China is lower than the average regional emission fluxes obtained for Hong Kong and the PRD, largely due to the vast 10 areas of barren land in Northwest China. Notably, the results of different studies vary dramatically by province, mainly because of differences in input data and algorithms.

Compared to the global emission estimations of Guenther et al. (1995), the annual emissions of isoprene and monoterpenes in China accounted for about $2.0 \%$ of the total global amount $(629.9 \mathrm{TgC})$. Therein, isoprene was responsible for $1.8 \%$ of global emissions $(502.9 \mathrm{Tg} \mathrm{C})$, and monoterpenes accounted for $2.8 \%$ of global emissions (127.0 Tg C). Thus, although China covered approximately $6 \%$ of the global land area, it only contributed $2 \%$ to global BVOC emissions. Currently, China is undergoing rapid land-cover changes and is now the world's leading nation in existing plantation area (24\% of the global total) (Geron et al., 2006) and implying a greater future impact on BVOC emission contributions.

Generally, in comparison with previous BVOC inventories, the present study considers more controlling factors, including LAI and leaf age, which play important roles in the seasonal variations and spatial differences of BVOC emissions. The input meteorological data used in this study was also of higher resolution than the observed meteorological data and thus may generate more precise estimation results and distributions of BVOC emissions.

\section{ACPD}

12, 6551-6592, 2012

\section{Estimation of BVOC emissions in China using MODIS data}

M. Li et al.

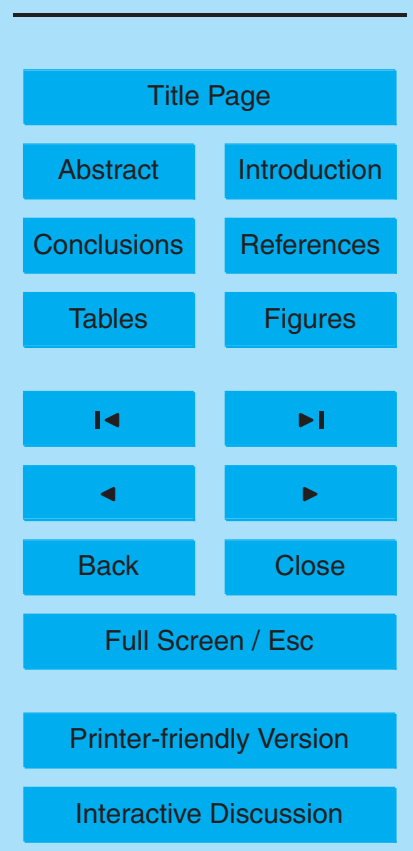




\section{Discussion of uncertainties}

The uncertainties in our estimations of BVOC emissions are substantial because of a number of factors. It is difficult to quantify the uncertainties in BVOC emissions studies for lack of data. Here, we merely try to identify the main sources of uncertainties to 5 better understand the results and improve future research directions.

\subsection{Emission algorithms}

Experimental evidence over the past two decades implicated a number of physical and biological factors in modifying the capacity of a leaf to emit BVOCs. Hence, the uncertainties in the emission algorithms used to describe the dependence of emissions have been a significant source of the overall uncertainty.

1. To date, Guenther's algorithms represent the most advanced approach for reliable determinations of BVOC emissions and are widely used. However, like all empirical modeling approaches, Guenther's algorithms suffer from uncertainties related to first, whether empirical relationships based on short-term and limited measurements can be generalized to describe long-term changes, and second the lack of process-understanding regarding isoprene production and emission (Pacifico et al., 2009).

2. The algorithms of light and temperature dependence by Guenther et al. (2006) require a set of input parameters, and as demonstrated herein, even minor errors in the parameterized coefficients substantially affect daily and maximum fluxes (Guenther et al., 1993; Arneth et al., 2008). Observations in boreal or subarctic environments have suggested that BVOC emissions may increase more steeply than indicated by the standard parameter values (Hakola et al., 1998; Rinne et al., 2000; Janson and de Serves, 2001; Arneth et al., 2008), posing great challenges to the algorithm relationships and coefficients in MEGAN.

\section{Estimation of BVOC emissions in China using MODIS data}

M. Li et al.

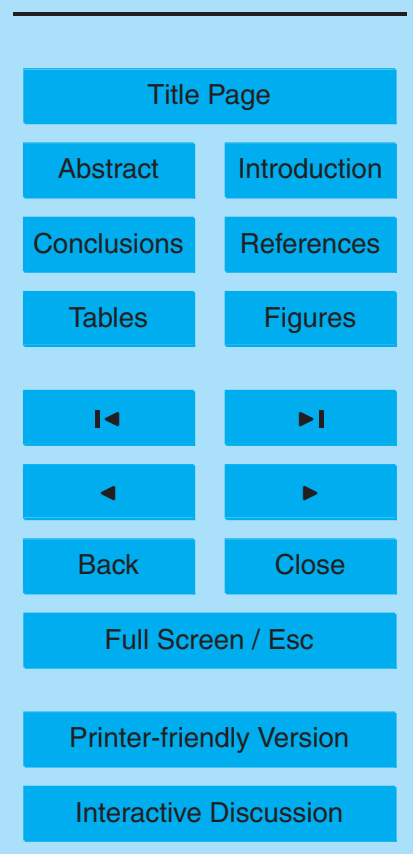

Interactive Discussion 
3. Additionally, the algorithms in this study also simplified the spatial distributions of solar radiation, leaf temperature and LAl within the canopy, neglecting the extinction of solar radiation as a function of the LAI, the distribution of LAI values inside the canopy, and the fractions of shaded and sunlit parts at each vertical layer (Karl et al., 2009). However, previous studies have found that the interception of solar radiation by a vegetation canopy generally yields an exponential decrease in radiation intensity as the canopy is descended, and whether a simple or a detailed canopy environment is considered might greatly influence the estimation results (Lamb et al., 1993, 1996; Muller et al., 2008; Karl et al., 2009). Hence, the detailed canopy environmental model, provided as an option with MEGANv2.1, may provide a more reliable result.

4. Finally, although the parameterized algorithms adopted in this study consider the main controlling factors in BVOC emissions, there are still many other influencing factors, such as humidity, wind speed, $\mathrm{CO}_{2}$ concentration, and environmental stresses, that require further consideration (and whose lack of adequate consideration to this point is largely due to insufficient data and their obscure relationships) (Guenther et al., 2006). In particular, several studies have focused on the influence of $\mathrm{CO}_{2}$ and have shown that elevated $\mathrm{CO}_{2}$ concentrations inhibited isoprene emissions, while low $\mathrm{CO}_{2}$ concentrations enhanced isoprene emission. These results indicate that great changes in BVOC emissions might be projected for future climate warming scenarios (Arneth et al., 2007a; Arneth et al., 2007b; Calfapietra et al., 2008; Heald et al., 2009; Wilkinson et al., 2009). The most recent study introducing an empirical factor in MEGAN to account for the direct effects of $\mathrm{CO}_{2}$ on isoprene emissions was described in detail in Heald et al. (2009) and may provide a promising new direction for accurate estimations of BVOCs.

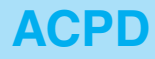

12, 6551-6592, 2012

\section{Estimation of BVOC emissions in China using MODIS data}

M. Li et al.

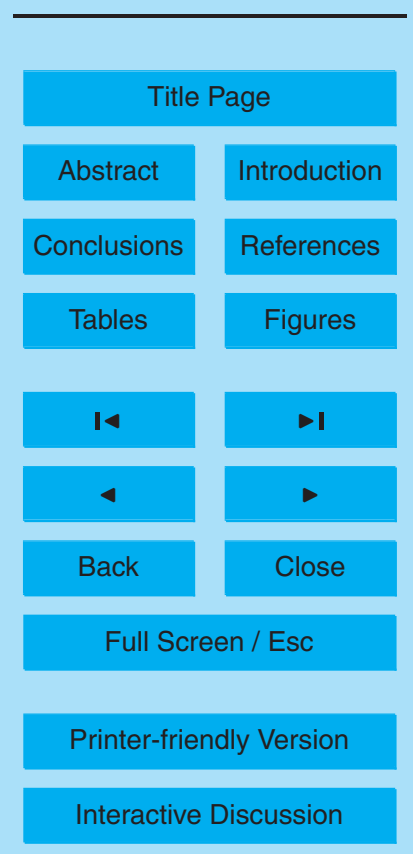




\subsection{Emission factors}

The emission factor dataset in this study was based on species-specific emission factors and land-cover information derived from ground measurement inventories, such as regional tree inventories, satellite-based inventories and eco-region descriptions 5 (Guenther et al., 2006). Thus, the uncertainties associated with emission factors predominantly arose from plant misidentifications and errors in BVOC emission measurements. Errors from misidentification are likely quite low because professional botanical experts were employed for plant identification (Klinger et al., 2002) and the validity of the satellite data was verified in other studies (Justice et al., 2002; Wang et al., 2011).

10 Hence, uncertainties in the BVOC emissions determined for a given species should predominantly result from inaccurate determinations of BVOC emissions and from discrepancies between assigned versus actual EFs.

Species-level EFs were compiled by Wiedinmyer et al. (2004) from published measurements. The determination of emission capacity were based on direct enclosure 15 flux measurements (Wiedinmyer et al., 2004), above-canopy isoprene flux measurements (Guenther et al., 1996; Guenther and Hills, 1998) or inverse modeling and gradient approaches (Greenberg et al., 1999; Wiedinmyer et al., 2004) conducted abroad, and the results are associated with substantial uncertainties due to the measurement techniques and our limited understanding of the complex conversion process within the canopy (Guenther et al., 2006).

Additionally, previous studies indicated that the emission capacities differed considerably within plants, and there were no obvious or consistent taxonomic relationships in terms of non-emitters or emitters, even within the same genus (Pacifico et al., 2009). Hence, it may not be appropriate to directly extrapolate the measured EFs from cer25 tain plant species to similar unmeasured family members. In particular, in comparison with trees, there are relatively few measurements of emission factors for shrubs, grasses and other plant species. Because of the scarcity of measurements relative to the large variability of plants on Earth and the inevitable lumping of a large number
ACPD

$12,6551-6592,2012$

\section{Estimation of BVOC emissions in China using MODIS data}

M. Li et al.

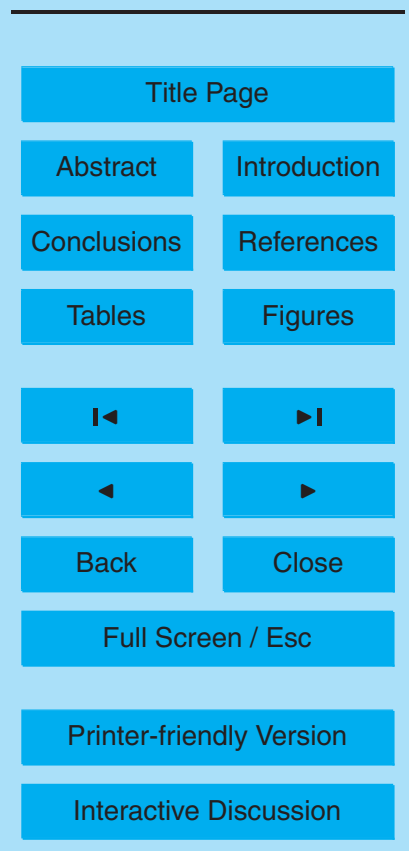


of plant species into functional groups, there may be great variations between BVOC estimation values for/in China that are obtained locally and those obtained via foreign measurements.

\subsection{Other input data}

5 In our study, highly resolved MM5 outputs were used to drive the estimation. In addition, we updated the land-use and vegetation data in MM5 to improve the simulation performance, but other land surface parameters, e.g., albedo, surface emissivity and surface temperature, still required further updates (de Foy et al., 2006; Meng et al., 2009).

10 Seasonal changes in vegetation and physiological activities, as reflected in LAI values calculated from the remote sensing input, influenced emissions via variations in the amount of emitting leaf biomass. Uncertainties in the determination of vegetation abundance (LAI) arise from satellite measurements and retrieval algorithm errors (Justice et al., 2002; Tian et al., 2002).

15 Although the present study has made obvious improvements in the methodology and input data, there is still a considerable degree of uncertainty, and there is much more to investigate, including creating a typical and representative map of local BVOC emission factors and improving the estimation algorithms to reduce uncertainties.

\section{Conclusions}

Using MODIS-MM5-MEGAN, we estimated the total emission and spatial-temporal distributions of BVOC emissions from terrestrial ecosystems in China for the year 2006. The introduction of MODIS data and comprehensive consideration of influence factors may potentially improve the estimation results. The annual total emission budget of BVOCs was roughly estimated to be $12.97 \mathrm{TgC}$. Isoprene, with an annual emission budget of $9.36 \mathrm{TgC}$, was the most abundant species (71.6\%), followed by $\alpha$-pinene
12, 6551-6592, 2012

\section{Estimation of BVOC emissions in China using MODIS data}

M. Li et al.

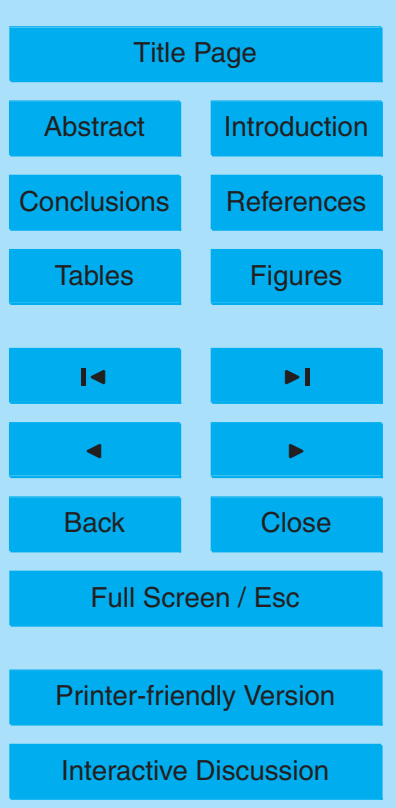


(1.24 Tg C, $9.8 \%)$ and $\beta$-pinene $(0.81 \mathrm{TgC}, 6.4 \%)$. Spatially, isoprene emission centered in Northeast and South China, with Yunnan contributing the largest $(9.5 \%)$, followed by Hunan $(7.9 \%)$ and Sichuan $(7.0 \%)$. While monoterpene emissions centered in Southeast China, where coniferous forests were extensively distributed and the three 5 top-ranking emitters were Guangxi (9.9\%), Yunnan (9.8\%) and Hunan $(8.1 \%)$. Temporally, the seasonal and diurnal cycles of solar radiation and temperature as well as plant growth jointly led to corresponding strong variabilities in BVOC emissions. Generally, BVOC emission rates peaked in July and August, with daily maximum values occurring at about 13:00 14:00 (BJT) and lowest values occurring at night. The strong 10 temporal cycle of BVOC emissions could have an important effect on the formation of secondary pollutants.

The BVOC emission estimations presented in this study initiated an attempt to provide a systematic and real-time update of high-resolution BVOC emissions in China. On the basis of this study, we will further investigate the role of BVOCs in SOA formation and global climate change using a three-dimensional atmospheric chemical and transport model, with efforts to quantitatively evaluate the role of BVOCs in the troposphere and provide information that is useful for local administrative decisions.

\section{Supplementary material related to this article is available online at: http://www.atmos-chem-phys-discuss.net/12/6551/2012/ acpd-12-6551-2012-supplement.pdf.}

Acknowledgements. The MODIS products were provided by Land Process Distributed Active Archive Center (LPDAAC), USA. This study was funded by the National Natural Science Foundation of China (40975088) and the Public Welfare Projects for Environmental Protection (200809018).

\section{ACPD}

12, 6551-6592, 2012

\section{Estimation of BVOC emissions in China using MODIS data}

M. Li et al.

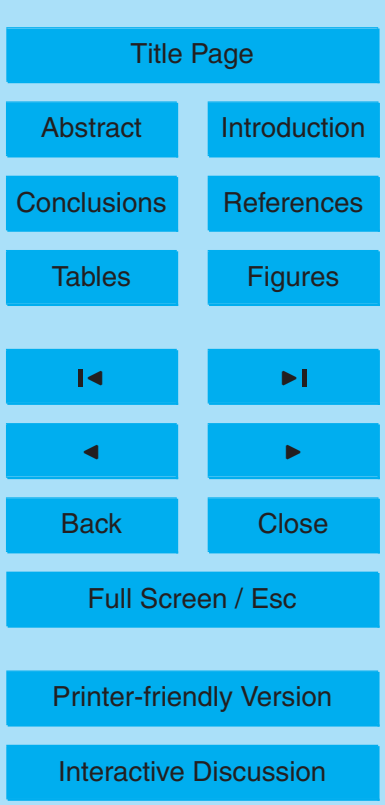




\section{References}

Arneth, A., Miller, P. A., Scholze, M., Hickler, T., Schurgers, G., Smith, B., and Prentice, I. C.: $\mathrm{CO}_{2}$ inhibition of global terrestrial isoprene emissions: Potential implications for atmospheric chemistry, Geophys. Res. Lett., 34, L18813, doi:10.1029/2007gl030615, 2007a.

5 Arneth, A., Niinemets, ., Pressley, S., Bck, J., Hari, P., Karl, T., Noe, S., Prentice, I. C., Serça, D., Hickler, T., Wolf, A., and Smith, B.: Process-based estimates of terrestrial ecosystem isoprene emissions: incorporating the effects of a direct CO2-isoprene interaction, Atmos. Chem. Phys., 7, 31-53, doi:10.5194/acp-7-31-2007, 2007b.

Arneth, A., Monson, R. K., Schurgers, G., Niinemets, ., and Palmer, P. I.: Why are estimates of global terrestrial isoprene emissions so similar (and why is this not so for monoterpenes)?, Atmos. Chem. Phys., 8, 4605-4620, doi:10.5194/acp-8-4605-2008, 2008.

Ashworth, K., Wild, O., and Hewitt, C. N.: Sensitivity of isoprene emissions estimated using MEGAN to the time resolution of input climate data, Atmos. Chem. Phys., 10, 1193-1201, doi:10.5194/acp-10-1193-2010, 2010.

15 Atkinson, B. W.: Numerical modelling of urban heat-island intensity, Bound-Lay. Meteorol., 109, 285-310, 2003.

Atkinson, R. and Arey, J.: Gas-phase tropospheric chemistry of biogenic volatile organic compounds: a review, Atmos. Environ., 37, S197-S219, doi:10.1016/S1352-2310(03)00391-1, 2003.

20 Benjamin, M. T., Sudol, M., Vorsatz, D., and Winer, A. M.: A spatially and temporally resolved biogenic hydrocarbon emissions inventory for the California South Coast Air Basin, Atmos. Environ., 31, 3087-3100, 1997.

Benkovitz, C. M., Schwartz, S. E., Jensen, M. P., Miller, M. A., Easter, R. C., and Bates, T. S.: Modeling atmospheric sulfur over the Northern Hemisphere during the Aerosol Characterization Experiment 2 experimental period, J. Geophys. Res.-Atmos., 109, D22207, doi:10.1029/2004jd004939, 2004.

Calfapietra, C., Mugnozza, G. S., Karnosky, D. F., Loreto, F., and Sharkey, T. D.: Isoprene emission rates under elevated $\mathrm{CO}_{2}$ and $\mathrm{O}_{3}$ in two field-grown aspen clones differing in their sensitivity to $\mathrm{O}_{3}$, New Phytologist, 179, 55-61, doi:10.1111/j.1469-8137.2008.02493.x, 2008.

Crawford, T. M., Stensrud, D. J., Mora, F., Merchant, J. W., and Wetzel, P. J.: Value of incorporating satellite-derived land cover data in MM5/PLACE for simulating surface temperatures, J. Hydrometeorol., 2, 453-468, 2001.

\section{Estimation of BVOC emissions in China using MODIS data}

M. Li et al.

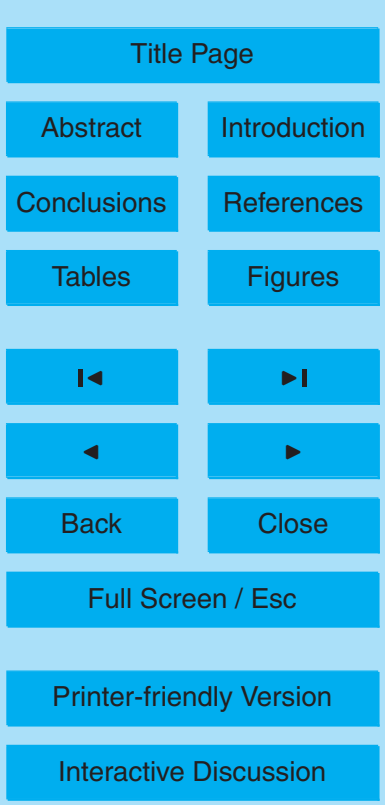


de Foy, B., Molina, L. T., and Molina, M. J.: Satellite-derived land surface parameters for mesoscale modelling of the Mexico City basin, Atmos. Chem. Phys., 6, 1315-1330, doi:10.5194/acp-6-1315-2006, 2006.

Ge, J. J., Qi, J. G., and Lofgren, B.: Use of vegetation properties from EOS observations for land-climate modeling in East Africa, J. Geophys. Res.-Atmos., 113, D15101, doi:10.1029/2007jd009628, 2008.

Geron, C., Owen, S., Guenther, A., Greenberg, J., Rasmussen, R., Bai, J. H., Li, Q. J., and Baker, B.: Volatile organic compounds from vegetation in southern Yunnan Province, China: Emission rates and some potential regional implications, Atmos. Environ., 40, 1759-1773, doi:10.1016/j.atmosenv.2005.11.022, 2006.

Goldstein, A. H. and Galbally, I. E.: Known and unexplored organic constituents in the Earth's atmosphere, Geochim. Cosmochim. Ac., 73, A449-A449, 2009.

Greenberg, J. P., Guenther, A., Zimmerman, P., Baugh, W., Geron, C., Davis, K., Helmig, D., and Klinger, L. F.: Tethered balloon measurements of biogenic VOCs in the atmospheric

15 boundary layer, Atmos. Environ., 33, 855-867, 1999.

Griffin, R. J., Cocker, D. R., Flagan, R. C., and Seinfeld, J. H.: Organic aerosol formation from the oxidation of biogenic hydrocarbons, J. Geophys. Res.-Atmos., 104, 3555-3567, 1999.

Guenther, A., Hewitt, C. N., Erickson, D., Fall, R., Geron, C., Graedel, T., Harley, P., Klinger, L., Lerdau, M., Mckay, W. A., Pierce, T., Scholes, B., Steinbrecher, R., Tallamraju, R., Taylor, J., and Zimmerman, P.: A Global-Model of Natural Volatile Organic-Compound Emissions, J. Geophys. Res.-Atmos., 100, 8873-8892, 1995.

Guenther, A., Greenberg, J., Harley, P., Helmig, D., Klinger, L., Vierling, L., Zimmerman, P., and Geron, C.: Leaf, branch, stand and landscape scale measurements of volatile organic compound fluxes from US woodlands, Tree Physiol., 16, 17-24, 1996.

Guenther, A., Archer, S., Greenberg, J., Harley, P., Helmig, D., Klinger, L., Vierling, L., Wildermuth, M., Zimmerman, P., and Zitzer, S.: Biogenic hydrocarbon emissions and landcover/climate change in a subtropical savanna, Phys. Chem. Earth. Pt. B, 24, 659-667, 1999.

Guenther, A.: The contribution of reactive carbon emissions from vegetation to the carbon balance of terrestrial ecosystems, Chemosphere, 49, 837-844, 2002.

Guenther, A., Karl, T., Harley, P., Wiedinmyer, C., Palmer, P. I., and Geron, C.: Estimates of global terrestrial isoprene emissions using MEGAN (Model of Emissions of Gases and Aerosols from Nature), Atmos. Chem. Phys., 6, 3181-3210, doi:10.5194/acp-6-3181-2006,

\section{Estimation of BVOC emissions in China using MODIS data}

M. Li et al.

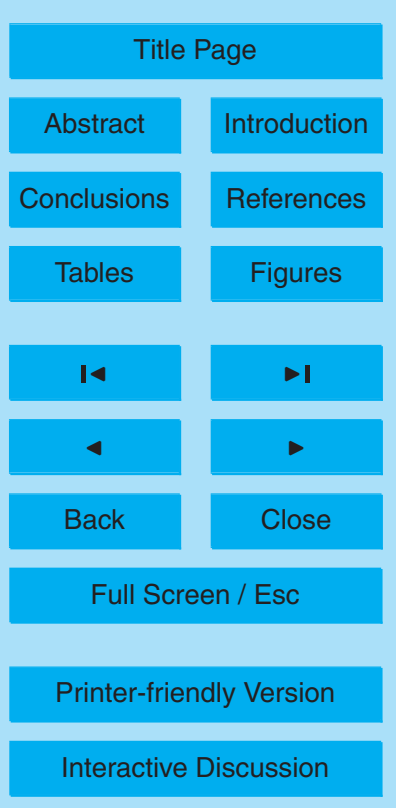


2006.

Guenther, A. B., Zimmerman, P. R., Harley, P. C., Monson, R. K., and Fall, R.: Isoprene and Monoterpene Emission Rate Variability - Model Evaluations and Sensitivity Analyses, J. Geophys. Res.-Atmos., 98, 12609-12617, 1993.

5 Guenther, A. B. and Hills, A. J.: Eddy covariance measurement of isoprene fluxes, J. Geophys. Res.-Atmos., 103, 13145-13152, 1998.

Gutman, G. and Ignatov, A.: The derivation of the green vegetation fraction from NOAA/AVHRR data for use in numerical weather prediction models, Int. J. Remote. Sens., 19, 1533-1543, 1998.

10 Hakola, H., Rinne, J., and Laurila, T.: The hydrocarbon emission rates of tea-leafed willow (Salix phylicifolia), silver birch (Betula pendula) and European aspen (Populus tremula), Atmos. Environ., 32, 1825-1833, 1998.

Hallquist, M., Wenger, J. C., Baltensperger, U., Rudich, Y., Simpson, D., Claeys, M., Dommen, J., Donahue, N. M., George, C., Goldstein, A. H., Hamilton, J. F., Herrmann, H., Hoffmann, T., linuma, Y., Jang, M., Jenkin, M. E., Jimenez, J. L., Kiendler-Scharr, A., Maenhaut, W., McFiggans, G., Mentel, Th. F., Monod, A., Prvt, A. S. H., Seinfeld, J. H., Surratt, J. D., Szmigielski, R., and Wildt, J.: The formation, properties and impact of secondary organic aerosol: current and emerging issues, Atmos. Chem. Phys., 9, 5155-5236, doi:10.5194/acp9-5155-2009, 2009.

20 Heald, C. L., Wilkinson, M. J., Monson, R. K., Alo, C. A., Wang, G. L., and Guenther, A.: Response of isoprene emission to ambient $\mathrm{CO}_{2}$ changes and implications for global budgets, Global Change Biol, 15, 1127-1140, doi:10.1111/j.1365-2486.2008.01802.x, 2009.

Hoffmann, T., Odum, J. R., Bowman, F., Collins, D., Klockow, D., Flagan, R. C., and Seinfeld, J. H.: Formation of organic aerosols from the oxidation of biogenic hydrocarbons, J. Atmos.

25 Chem., 26, 189-222, 1997.

Jakubauskas, M., Kindscher, K., Fraser, A., Debinski, D., and Price, K. P.: Close-range remote sensing of aquatic macrophyte vegetation cover, Int. J. Remote. Sens., 21, 3533-3538, 2000.

Janson, R. and de Serves, C.: Acetone and monoterpene emissions from the boreal forest in northern Europe, Atmos. Environ., 35, 4629-4637, 2001.

Jiang, L., Kogan, F. N., Guo, W., Tarpley, J. D., Mitchell, K. E., Ek, M. B., Tian, Y. H., Zheng, W. Z., Zou, C. Z., and Ramsay, B. H.: Real-time weekly global green vegetation fraction derived from advanced very high resolution radiometer-based NOAA operational global vegetation

\section{Estimation of BVOC emissions in China using MODIS data}

M. Li et al.

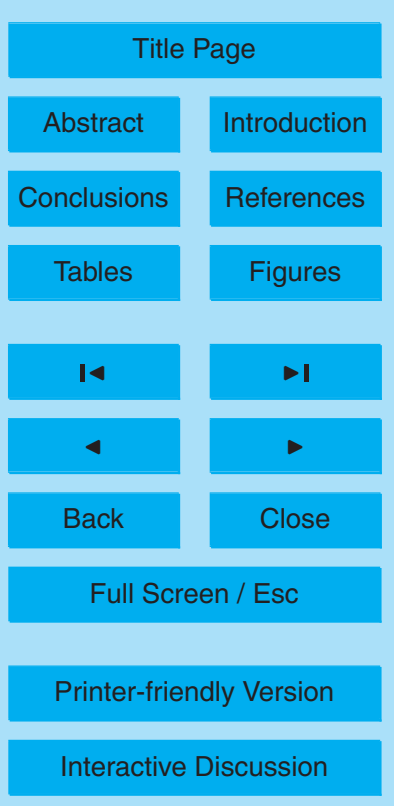


index (GVI) system, J. Geophys. Res.-Atmos., 115, D11114, doi:10.1029/2009jd013204, 2010.

Justice, C. O., Townshend, J. R. G., Vermote, E. F., Masuoka, E., Wolfe, R. E., Saleous, N., Roy, D. P., and Morisette, J. T.: An overview of MODIS Land data processing and product status, Remote Sens. Environ., 83, 3-15, 2002.

Kanakidou, M., Seinfeld, J. H., Pandis, S. N., Barnes, I., Dentener, F. J., Facchini, M. C., Van Dingenen, R., Ervens, B., Nenes, A., Nielsen, C. J., Swietlicki, E., Putaud, J. P., Balkanski, Y., Fuzzi, S., Horth, J., Moortgat, G. K., Winterhalter, R., Myhre, C. E. L., Tsigaridis, K., Vignati, E., Stephanou, E. G., and Wilson, J.: Organic aerosol and global climate modelling: a review, Atmos. Chem. Phys., 5, 1053-1123, doi:10.5194/acp-5-1053-2005, 2005.

Karl, M., Guenther, A., Kble, R., Leip, A., and Seufert, G.: A new European plant-specific emission inventory of biogenic volatile organic compounds for use in atmospheric transport models, Biogeosciences, 6, 1059-1087, doi:10.5194/bg-6-1059-2009, 2009.

Kesselmeier, J. and Staudt, M.: Biogenic volatile organic compounds (VOC): An overview on 15 emission, physiology and ecology, J. Atmos. Chem., 33, 23-88, 1999.

Kesselmeier, J., Ciccioli, P., Kuhn, U., Stefani, P., Biesenthal, T., Rottenberger, S., Wolf, A., Vitullo, M., Valentini, R., Nobre, A., Kabat, P., and Andreae, M. O.: Volatile organic compound emissions in relation to plant carbon fixation and the terrestrial carbon budget, Global Biogeochem. Cy., 16, 1126, doi:10.1029/2001gb001813, 2002.

Klinger, L. F., Li, Q. J., Guenther, A. B., Greenberg, J. P., Baker, B., and Bai, J. H.: Assessment of volatile organic compound emissions from ecosystems of China, J. Geophys. Res.-Atmos., 107, 4603, doi:10.1029/2001jd001076, 2002.

Kuhn, U., Andreae, M. O., Ammann, C., Arajo, A. C., Brancaleoni, E., Ciccioli, P., Dindorf, T., Frattoni, M., Gatti, L. V., Ganzeveld, L., Kruijt, B., Lelieveld, J., Lloyd, J., Meixner, F. X., Nobre, A. D., Pschl, U., Spirig, C., Stefani, P., Thielmann, A., Valentini, R., and Kesselmeier, J.: Isoprene and monoterpene fluxes from Central Amazonian rainforest inferred from towerbased and airborne measurements, and implications on the atmospheric chemistry and the local carbon budget, Atmos. Chem. Phys., 7, 2855-2879, doi:10.5194/acp-7-2855-2007, 2007.

30 Kurkowski, N. P., Stensrud, D. J., and Baldwin, M. E.: Assessment of implementing satellitederived land cover data in the Eta model, Weather Forecast., 18, 404-416, 2003.

Kuzma, J., Nemecekmarshall, M., Pollock, W. H., and Fall, R.: Bacteria Produce the Volatile Hydrocarbon Isoprene, Curr. Microbiol., 30, 97-103, 1995.

\section{Estimation of BVOC emissions in China using MODIS data}

M. Li et al.

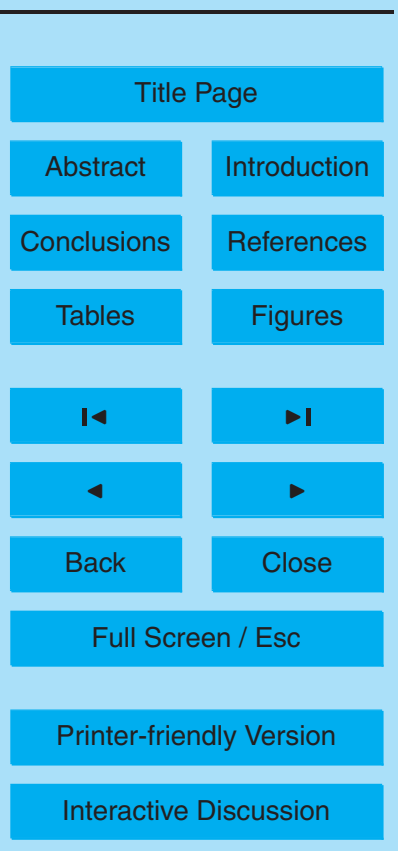


Lamb, B., Gay, D., Westberg, H., and Pierce, T.: A Biogenic Hydrocarbon Emission Inventory for the USA Using a Simple Forest Canopy Model, Atmos. Environ, 27, 1673-1690, 1993.

Lamb, B., Pierce, T., Baldocchi, D., Allwine, E., Dilts, S., Westberg, H., Geron, C., Guenther, A., Klinger, L., Harley, P., and Zimmerman, P.: Evaluation of forest canopy models for estimating isoprene emissions, J Geophys. Res.-Atmos., 101, 22787-22797, 1996.

Lane, T. E. and Pandis, S. N.: Predicted secondary organic aerosol concentrations from the oxidation of isoprene in the Eastern United States, Environ. Sci. Technol., 41, 3984-3990, doi:10.1021/Es061312q, 2007.

Leung, D. Y. C., Wong, P., Cheung, B. K. H., and Guenther, A.: Improved land cover and emission factors for modeling biogenic volatile organic compounds emissions from Hong Kong, Atmos. Environ., 44, 1456-1468, doi:10.1016/j.atmosenv.2010.01.012, 2010.

Liao, H., Henze, D. K., Seinfeld, J. H., Wu, S. L., and Mickley, L. J.: Biogenic secondary organic aerosol over the United States: Comparison of climatological simulations with observations, J. Geophys. Res.-Atmos., 112, D06201, doi:10.1029/2006jd007813, 2007.

McKay, W. A., Turner, M. F., Jones, B. M. R., and Halliwell, C. M.: Emissions of hydrocarbons from marine phytoplankton - Some results from controlled laboratory experiments, Atmos. Environ., 30, 2583-2593, 1996.

Meng, X. H., Lu, S. H., Zhang, T. T., Guo, J. X., Gao, Y. H., Bao, Y., Wen, L. J., Luo, S. Q., and Liu, Y. P.: Numerical simulations of the atmospheric and land conditions over the Jinta oasis in northwestern China with satellite-derived land surface parameters, J. Geophys. Res.-Atmos., 114, D06114, doi:10.1029/2008jd010360, 2009.

Molders, $\mathrm{N}$.: On the uncertainty in mesoscale modeling caused by surface parameters, Meteorol. Atmos. Phys., 76, 119-141, 2001.

Monks, P. S., Granier, C., Fuzzi, S., Stohl, A., Williams, M. L., Akimoto, H., Amann, M., Baklanov, A., Baltensperger, U., Bey, I., Blake, N., Blake, R. S., Carslaw, K., Cooper, O. R., Dentener, F., Fowler, D., Fragkou, E., Frost, G. J., Generoso, S., Ginoux, P., Grewe, V., Guenther, A., Hansson, H. C., Henne, S., Hjorth, J., Hofzumahaus, A., Huntrieser, H., Isaksen, I. S. A., Jenkin, M. E., Kaiser, J., Kanakidou, M., Klimont, Z., Kulmala, M., Laj, P., Lawrence, M. G., Lee, J. D., Liousse, C., Maione, M., McFiggans, G., Metzger, A., Mieville, A., Moussiopoulos, N., Orlando, J. J., O'Dowd, C. D., Palmer, P. I., Parrish, D. D., Petzold, A., Platt, U., Poschl, U., Prevot, A. S. H., Reeves, C. E., Reimann, S., Rudich, Y., Sellegri, K., Steinbrecher, R., Simpson, D., ten Brink, H., Theloke, J., van der Werf, G. R., Vautard, R., Vestreng, V., Vlachokostas, C., and von Glasow, R.: Atmospheric composition change - global and regional

\section{ACPD}

12, 6551-6592, 2012

\section{Estimation of BVOC emissions in China using MODIS data}

M. Li et al.

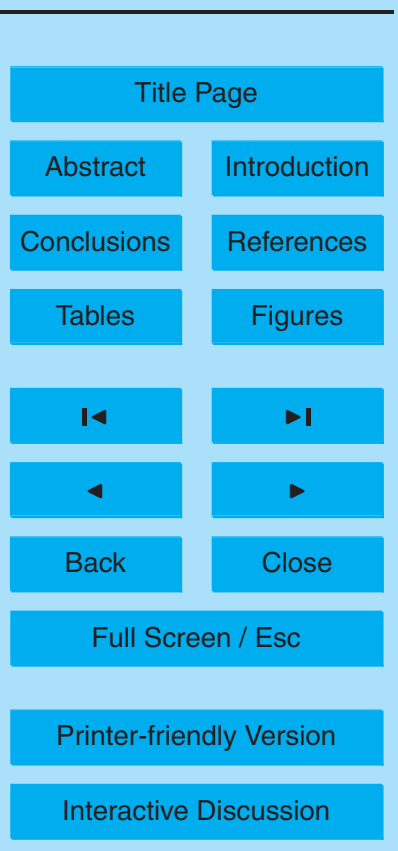


air quality, Atmos. Environ., 43, 5268-5350, doi:0.1016/j.atmosenv.2009.08.021, 2009.

Müller, J.-F., Stavrakou, T., Wallens, S., De Smedt, I., Van Roozendael, M., Potosnak, M. J., Rinne, J., Munger, B., Goldstein, A., and Guenther, A. B.: Global isoprene emissions estimated using MEGAN, ECMWF analyses and a detailed canopy environment model, Atmos.

$5 \quad$ Chem. Phys., 8, 1329-1341, doi:10.5194/acp-8-1329-2008, 2008.

Pacifico, F., Harrison, S. P., Jones, C. D., and Sitch, S.: Isoprene emissions and climate, Atmos. Environ., 43, 6121-6135, doi:10.1016/j.atmosenv.2009.09.002, 2009.

Perraud, V., Bruns, E. A., Ezell, M. J., Johnson, S. N., Yu, Y., Alexander, M. L., Zelenyuk, A., Imre, D., and Pitts, B. J. F.: Contribution from $\mathrm{O}_{3}$ chemistry to secondary organic aerosol formation during the $\mathrm{NO}_{3}$ radical-initiated oxidation of alpha-pinene, Abstracts of Papers of the Am. Chem. Soc., 241, 2011.

Pielke, R. A., Marland, G., Betts, R. A., Chase, T. N., Eastman, J. L., Niles, J. O., Niyogi, D. D. S., and Running, S. W.: The influence of land-use change and landscape dynamics on the climate system: relevance to climate-change policy beyond the radiative effect of greenhouse gases, Philos. T. Roy. Soc. A., 360, 1705-1719, doi:10.1098/rsta.2002.1027, 2002.

Purevdorj, T., Tateishi, R., Ishiyama, T., and Honda, Y.: Relationships between percent vegetation cover and vegetation indices, Int. J. Remote. Sens., 19, 3519-3535, 1998.

Rinne, J., Tuovinen, J. P., Laurila, T., Hakola, H., Aurela, M., and Hypen, H.: Measurements of hydrocarbon fluxes by a gradient method above a northern boreal forest, Agr. Forest. Meteorol., 102, 25-37, 2000.

Ryerson, T. B., Trainer, M., Holloway, J. S., Parrish, D. D., Huey, L. G., Sueper, D. T., Frost, G. J., Donnelly, S. G., Schauffler, S., Atlas, E. L., Kuster, W. C., Goldan, P. D., Hubler, G., Meagher, J. F., and Fehsenfeld, F. C.: Observations of ozone formation in power plant plumes and implications for ozone control strategies, Science, 292, 719-723, 2001.

Sakulyanontvittaya, T., Duhl, T., Wiedinmyer, C., Helmig, D., Matsunaga, S., Potosnak, M., Milford, J., and Guenther, A.: Monoterpene and sesquiterpene emission estimates for the United States, Environ. Sci. Technol., 42, 1623-1629, doi:10.1021/Es702274e, 2008.

Schell, B., Ackermann, I. J., Hass, H., Binkowski, F. S., and Ebel, A.: Modeling the formation of secondary organic aerosol within a comprehensive air quality model system, J. Geophys. Res.-Atmos., 106, 28275-28293, 2001.

Streets, D. G., Bond, T. C., Carmichael, G. R., Fernandes, S. D., Fu, Q., He, D., Klimont, Z., Nelson, S. M., Tsai, N. Y., Wang, M. Q., Woo, J. H., and Yarber, K. F.: An inventory of gaseous and primary aerosol emissions in Asia in the year 2000, J. Geophys. Res.-Atmos.,

\section{ACPD}

12, 6551-6592, 2012

\section{Estimation of BVOC emissions in China using MODIS data}

M. Li et al.

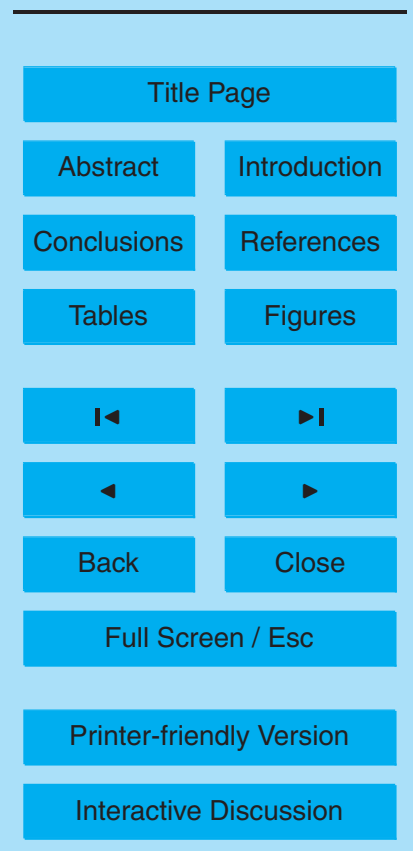


108, 8809, doi:10.1029/2002jd003093, 2003.

Szidat, S., Jenk, T. M., Synal, H. A., Kalberer, M., Wacker, L., Hajdas, I., Kasper-Giebl, A., and Baltensperger, U.: Contributions of fossil fuel, biomass-burning, and biogenic emissions to carbonaceous aerosols in Zurich as traced by (14)C, J. Geophys. Res.-Atmos., 111, D07206, 5 doi:10.1029/2005jd006590, 2006.

Tian, Y., Dickinson, R. E., Zhou, L., Myneni, R. B., Friedl, M., Schaaf, C. B., Carroll, M., and Gao, F.: Land boundary conditions from MODIS data and consequences for the albedo of a climate model, Geophys. Res. Lett., 31, L05504, doi:10.1029/2003gl019104, 2004.

Tian, Y. H., Woodcock, C. E., Wang, Y. J., Privette, J. L., Shabanov, N. V., Zhou, L. M., Zhang, Y., Buermann, W., Dong, J. R., Veikkanen, B., Hame, T., Andersson, K., Ozdogan, M., Knyazikhin, Y., and Myneni, R. B.: Multiscale analysis and validation of the MODIS LAI product - I. Uncertainty assessment, Remote. Sens. Environ., 83, 414-430, 2002.

Tie, X. X., Li, G. H., Ying, Z. M., Guenther, A., and Madronich, S.: Biogenic emissions of isoprenoids and NO in China and comparison to anthropogenic emissions, Sci Total Environ, 371, 238-251, doi:10.1016/j.scitotenv.2006.06.025, 2006.

Tsui, J. K. Y., Guenther, A., Yip, W. K., and Chen, F.: A biogenic volatile organic compound emission inventory for Hong Kong, Atmos. Environ., 43, 6442-6448, doi:10.1016/j.atmosenv.2008.01.027, 2009.

Wang, Q. G., Han, Z. W., Wang, T. J., and Higano, Y.: An estimate of biogenic emissions of volatile organic compounds during summertime in China, Environ. Sci. Pollut. R, 14, 69-75, doi:10.1065/espr2007.01.376, 2007.

Wang, X. M., Situ, S. P., Guenther, A., Chen, F., Wu, Z. Y., Xia, B. C., and Wang, T. J.: Spatiotemporal variability of biogenic terpenoid emissions in Pearl River Delta, China, with highresolution land-cover and meteorological data, Tellus B, 63, 241-254, doi:10.1111/j.16000889.2010.00523.x, 2011.

Wang, Z. H., Bai, Y. H., and Zhang, S. Y.: A biogenic volatile organic compounds emission inventory for Beijing, Atmos Environ, 37, 3771-3782, doi:10.1016/S1352-2310(03)00462-X, 2003.

Went, F. W.: Blue Hazes in the Atmosphere, Nature, 187, 641-643, 1960.

so Wilkinson, M. J., Monson, R. K., Trahan, N., Lee, S., Brown, E., Jackson, R. B., Polley, H. W., Fay, P. A., and Fall, R.: Leaf isoprene emission rate as a function of atmospheric $\mathrm{CO}_{2}$ concentration, Global Change Biol., 15, 1189-1200, doi:10.1111/j.1365-2486.2008.01803.x, 2009.

\section{ACPD}

12, 6551-6592, 2012

\section{Estimation of BVOC emissions in China using MODIS data}

M. Li et al.

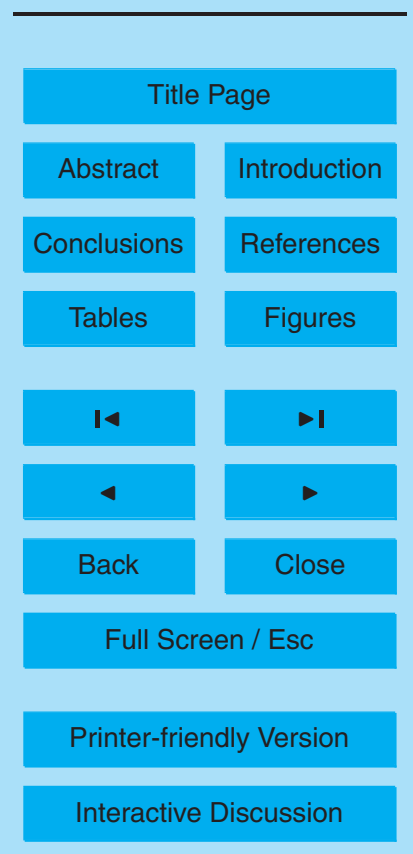


Wittich, K. P., and Hansing, O.: Area-Averaged Vegetative Cover Fraction Estimated from Satellite Data, Int. J. Biometeorol., 38, 209-215, 1995.

Yucel, I.: Effects of implementing MODIS land cover and albedo in MM5 at two contrasting US regions, J. Hydrometeorol., 7, 1043-1060, 2006.

5 Zemankova, K. and Brechler, J.: Emissions of biogenic VOC from forest ecosystems in central Europe: Estimation and comparison with anthropogenic emission inventory, Environ. Pollut., 158, 462-469, doi:10.1016/j.envpol.2009.08.032, 2010.

Zhang, Q., Streets, D. G., Carmichael, G. R., He, K. B., Huo, H., Kannari, A., Klimont, Z., Park, I. S., Reddy, S., Fu, J. S., Chen, D., Duan, L., Lei, Y., Wang, L. T., and Yao, Z. L.: Asian emissions in 2006 for the NASA INTEX-B mission, Atmos. Chem. Phys., 9, 5131-5153, doi:10.5194/acp-9-5131-2009, 2009.

Zheng, J. Y., Zheng, Z. Y., Yu, Y. F., and Zhong, L. J.: Temporal, spatial characteristics and uncertainty of biogenic VOC emissions in the Pearl River Delta region, China, Atmos. Environ., 44, 1960-1969, doi:10.1016/j.atmosenv.2010.03.001, 2010.

\section{ACPD}

12, 6551-6592, 2012

\section{Estimation of BVOC emissions in China using MODIS data}

M. Li et al.
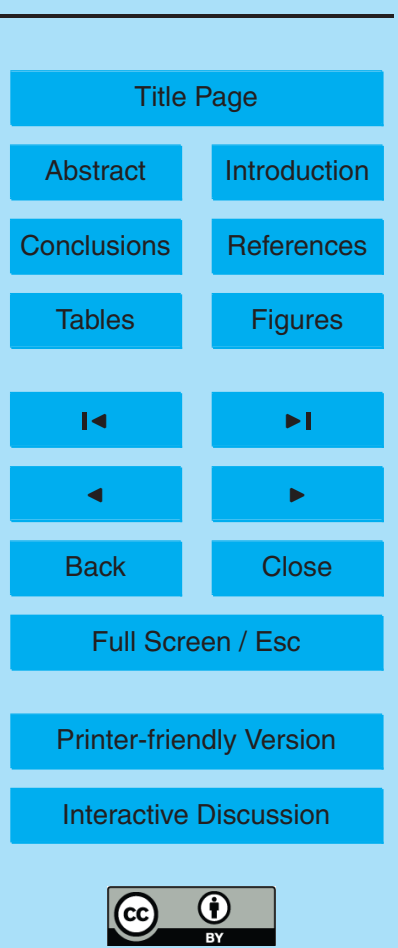


\section{ACPD}

12, 6551-6592, 2012

Table 1. Mapping of the land-use classes of MODIS to USGS classifications.

\begin{tabular}{llll}
\hline & \multicolumn{1}{c}{ MODIS } & \multicolumn{1}{c}{ USGS } \\
\hline Category & Land-use Description & Category & Land-use Description \\
\cline { 2 - 4 } & Water & 16 & Water bodies \\
1 & Evergreen Coniferous Forest & 14 & Evergreen Coniferous forest \\
2 & Evergreen Broadleaf Forest & 13 & Evergreen Broadleaf forest \\
3 & Deciduous Coniferous Forest & 12 & Deciduous Coniferous forest \\
4 & Deciduous Broadleaf Forest & 11 & Deciduous Broadleaf forest \\
5 & Mixed Forest & 15 & Mixed Forest \\
6 & Closed Shrubland & 8 & Shrubland \\
7 & Open Shrubland & 9 & Mixed Shrubland/Grass \\
8 & Woody savanna & 10 & Savanna \\
9 & Savanna & 10 & Savanna \\
10 & Grassland & 7 & Grassland \\
11 & Permanent wetland & 17 & Herb. Wetland \\
12 & Cropland & 5 & Crop/Grass Mosaic \\
13 & Urban and Built-up & 1 & Urban \\
14 & Cropland/Natural Vegetation Mosaic & 6 & Crop/Wood Mosaic \\
15 & Snow and Ice & 24 & Snow or Ice \\
16 & Barren or Sparsely Vegetated & 19 & Barren or Sparsely Vegetated \\
254 & Unclassified & 25 & No Data \\
\hline
\end{tabular}

\section{Estimation of BVOC emissions in China using MODIS data}

M. Li et al.

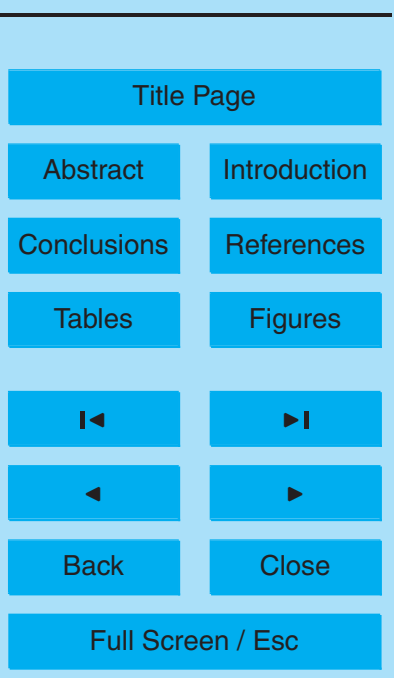

Printer-friendly Version

Interactive Discussion 
Table 2. Monthly emission budgets of BVOCs in China, as estimated by this study ( $\operatorname{Tg} \mathrm{C}$ per season or per year).

\begin{tabular}{|c|c|c|c|c|c|c|c|c|c|c|}
\hline \multirow[t]{2}{*}{ Season } & \multirow[t]{2}{*}{$\mathrm{ISO}^{\mathrm{b}}$} & \multicolumn{8}{|c|}{$M T^{b}$} & \multirow{2}{*}{ BVOCs $^{c}$} \\
\hline & & APIN & BPIN & 3-CAR & OCIM & LIMO & SABI & MYRC & Total & \\
\hline March & 0.16 & 0.03 & 0.02 & 0.02 & 0.01 & 0.01 & 0.01 & 0.00 & 0.10 & 0.26 \\
\hline April & 0.44 & 0.07 & 0.05 & 0.04 & 0.02 & 0.02 & 0.01 & 0.01 & 0.20 & 0.64 \\
\hline May & 0.85 & 0.12 & 0.08 & 0.07 & 0.03 & 0.03 & 0.02 & 0.01 & 0.35 & 1.20 \\
\hline Spring $^{a}$ & 1.46 & 0.22 & 0.15 & 0.12 & 0.06 & 0.05 & 0.03 & 0.02 & 0.65 & 2.11 \\
\hline June & 1.43 & 0.18 & 0.12 & 0.10 & 0.05 & 0.04 & 0.03 & 0.02 & 0.54 & 1.97 \\
\hline July & 2.41 & 0.26 & 0.17 & 0.14 & 0.07 & 0.06 & 0.04 & 0.02 & 0.76 & 3.17 \\
\hline August & 2.41 & 0.26 & 0.17 & 0.13 & 0.07 & 0.06 & 0.04 & 0.02 & 0.74 & 3.15 \\
\hline Summer $^{a}$ & 6.25 & 0.70 & 0.45 & 0.37 & 0.19 & 0.16 & 0.10 & 0.06 & 2.04 & 8.29 \\
\hline September & 0.89 & 0.14 & 0.09 & 0.08 & 0.03 & 0.03 & 0.02 & 0.01 & 0.40 & 1.29 \\
\hline October & 0.41 & 0.08 & 0.06 & 0.05 & 0.02 & 0.02 & 0.01 & 0.01 & 0.24 & 0.65 \\
\hline November & 0.15 & 0.04 & 0.03 & 0.02 & 0.01 & 0.01 & 0.01 & 0.00 & 0.11 & 0.26 \\
\hline Autumn ${ }^{a}$ & 1.46 & 0.26 & 0.17 & 0.15 & 0.06 & 0.06 & 0.04 & 0.02 & 0.75 & 2.21 \\
\hline December & 0.06 & 0.02 & 0.01 & 0.01 & 0.00 & 0.01 & 0.00 & 0.00 & 0.06 & 0.12 \\
\hline January & 0.05 & 0.02 & 0.01 & 0.01 & 0.00 & 0.00 & 0.00 & 0.00 & 0.06 & 0.11 \\
\hline February & 0.07 & 0.02 & 0.01 & 0.01 & 0.00 & 0.00 & 0.00 & 0.00 & 0.05 & 0.12 \\
\hline Winter $^{\mathrm{a}}$ & 0.19 & 0.06 & 0.04 & 0.03 & 0.01 & 0.01 & 0.01 & 0.01 & 0.17 & 0.36 \\
\hline Annual & 9.36 & 1.24 & 0.81 & 0.67 & 0.32 & 0.28 & 0.18 & 0.11 & 3.61 & 12.97 \\
\hline
\end{tabular}

a Spring: March, April and May; Summer: June, July and August; Autumn: September, October and November; Winter: December, January and February.

${ }^{\mathrm{b}}$ ISO, isoprene; MT, monoterpene; APIN, $\alpha$-pinene; BPIN, $\beta$-pinene; 3-CAR, 3-carene; OCIM, ocimene; LIMO, limonene; SABI, sabinene; MYRC, myrcene.

${ }^{\mathrm{C}}$ In this study, BVOCs refers to isoprene and seven monoterpene species.
$12,6551-6592,2012$

\section{Estimation of BVOC emissions in China using MODIS data}

M. Li et al.

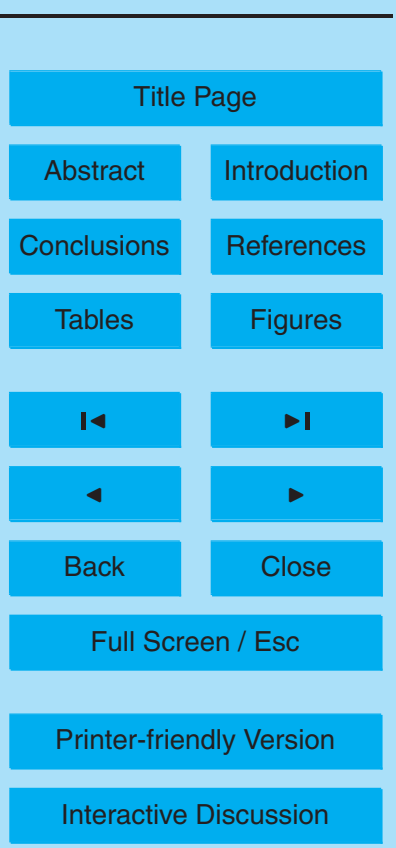


Table 3. Estimated BVOC emission budgets in this study and AVOC emission budgets calculated by Zhang et al. (2009) by province (Tg C per season or per year for BVOCs; Tg compound per year for AVOCs)

\begin{tabular}{|c|c|c|c|c|c|c|c|c|c|c|c|}
\hline \multirow[t]{2}{*}{ Province } & \multicolumn{2}{|c|}{ Spring } & \multicolumn{2}{|c|}{ Summer } & \multicolumn{2}{|c|}{ Autumn } & \multicolumn{2}{|c|}{ Winter } & \multicolumn{2}{|c|}{ total } & \multirow[t]{2}{*}{ AVOCs } \\
\hline & ISO & MT & ISO & MT & ISO & MT & ISO & MT & ISO & MT & \\
\hline Anhui & 0.04 & 0.02 & 0.20 & 0.06 & 0.03 & 0.02 & 0.00 & 0.00 & 0.27 & 0.09 & 0.96 \\
\hline Beijing & 0.00 & 0.00 & 0.02 & 0.00 & 0.00 & 0.00 & 0.00 & 0.00 & 0.02 & 0.01 & 0.50 \\
\hline Chongqing & 0.03 & 0.01 & 0.16 & 0.04 & 0.02 & 0.01 & 0.00 & 0.00 & 0.21 & 0.07 & 0.34 \\
\hline Fujian & 0.05 & 0.04 & 0.31 & 0.13 & 0.09 & 0.06 & 0.01 & 0.02 & 0.46 & 0.25 & 0.70 \\
\hline Gansu & 0.02 & 0.01 & 0.11 & 0.02 & 0.01 & 0.01 & 0.00 & 0.00 & 0.14 & 0.03 & 0.30 \\
\hline Guangdong & 0.06 & 0.05 & 0.25 & 0.12 & 0.13 & 0.08 & 0.02 & 0.02 & 0.46 & 0.28 & 1.78 \\
\hline Guangxi & 0.12 & 0.07 & 0.33 & 0.17 & 0.20 & 0.10 & 0.01 & 0.02 & 0.66 & 0.36 & 0.64 \\
\hline Guizhou & 0.05 & 0.03 & 0.19 & 0.08 & 0.05 & 0.03 & 0.00 & 0.00 & 0.29 & 0.14 & 0.48 \\
\hline Hainan & 0.05 & 0.02 & 0.07 & 0.02 & 0.04 & 0.02 & 0.01 & 0.01 & 0.17 & 0.07 & 0.12 \\
\hline Hebei & 0.01 & 0.00 & 0.12 & 0.03 & 0.02 & 0.01 & 0.00 & 0.00 & 0.15 & 0.04 & 1.52 \\
\hline Heilongjiang & 0.04 & 0.02 & 0.44 & 0.15 & 0.04 & 0.02 & 0.00 & 0.00 & 0.52 & 0.18 & 0.77 \\
\hline Henan & 0.03 & 0.01 & 0.12 & 0.04 & 0.02 & 0.01 & 0.00 & 0.00 & 0.17 & 0.06 & 1.29 \\
\hline Hong Kong $^{a}$ & 0.12 & 0.11 & 0.36 & 0.20 & 0.24 & 0.14 & 0.05 & 0.06 & 0.78 & 0.51 & 0.11 \\
\hline Hubei & 0.08 & 0.03 & 0.34 & 0.09 & 0.05 & 0.03 & 0.00 & 0.00 & 0.47 & 0.15 & 0.88 \\
\hline Hunan & 0.11 & 0.06 & 0.49 & 0.17 & 0.13 & 0.06 & 0.00 & 0.01 & 0.73 & 0.29 & 0.64 \\
\hline Inner Mongolia & 0.03 & 0.01 & 0.38 & 0.09 & 0.03 & 0.01 & 0.00 & 0.00 & 0.44 & 0.11 & 0.57 \\
\hline Jiangsu & 0.01 & 0.00 & 0.05 & 0.02 & 0.01 & 0.01 & 0.00 & 0.00 & 0.07 & 0.03 & 1.79 \\
\hline Jiangxi & 0.06 & 0.05 & 0.40 & 0.15 & 0.10 & 0.06 & 0.01 & 0.01 & 0.57 & 0.27 & 0.52 \\
\hline Jilin & 0.02 & 0.01 & 0.18 & 0.05 & 0.03 & 0.01 & 0.00 & 0.00 & 0.23 & 0.07 & 0.51 \\
\hline Liaoning & 0.01 & 0.00 & 0.09 & 0.03 & 0.02 & 0.01 & 0.00 & 0.00 & 0.12 & 0.04 & 0.97 \\
\hline Ningxia & 0.00 & 0.00 & 0.01 & 0.00 & 0.00 & 0.00 & 0.00 & 0.00 & 0.01 & 0.00 & 0.13 \\
\hline Qinghai & 0.00 & 0.00 & 0.07 & 0.01 & 0.01 & 0.00 & 0.00 & 0.00 & 0.08 & 0.02 & 0.07 \\
\hline Shaanxi & 0.07 & 0.02 & 0.32 & 0.06 & 0.03 & 0.01 & 0.00 & 0.00 & 0.42 & 0.10 & 0.49 \\
\hline Shandong & 0.01 & 0.01 & 0.05 & 0.02 & 0.01 & 0.01 & 0.00 & 0.00 & 0.07 & 0.03 & 2.09 \\
\hline Shanghai & 0.00 & 0.00 & & & & & & & & & \\
\hline Shanxi & 0.02 & 0.01 & 0.11 & 0.02 & 0.01 & 0.00 & 0.00 & 0.00 & 0.14 & 0.03 & 0.63 \\
\hline Sichuan & 0.10 & 0.04 & 0.49 & 0.14 & 0.06 & 0.04 & 0.01 & 0.01 & 0.66 & 0.23 & 1.31 \\
\hline Taiwan & 0.02 & 0.01 & 0.05 & 0.02 & 0.02 & 0.01 & 0.01 & 0.01 & 0.1 & 0.05 & - \\
\hline Tianjin & 0.00 & 0.00 & 0.00 & 0.00 & 0.00 & 0.00 & 0.00 & 0.00 & 0.00 & 0.00 & 0.38 \\
\hline Tibet & 0.07 & 0.02 & 0.15 & 0.04 & 0.05 & 0.02 & 0.02 & 0.01 & 0.29 & 0.10 & 0.01 \\
\hline Xinjiang & 0.01 & 0.00 & 0.12 & 0.02 & 0.01 & 0.00 & 0.00 & 0.00 & 0.14 & 0.02 & 0.39 \\
\hline Yunnan & 0.27 & 0.08 & 0.36 & 0.15 & 0.18 & 0.09 & 0.08 & 0.04 & 0.89 & 0.35 & 0.51 \\
\hline Zhejiang & 0.04 & 0.03 & 0.24 & 0.09 & 0.05 & 0.03 & 0.00 & 0.01 & 0.33 & 0.15 & 1.23 \\
\hline Total & 1.46 & 0.65 & 6.25 & 2.04 & 1.46 & 0.75 & 0.18 & 0.17 & 9.35 & 3.61 & 23.25 \\
\hline
\end{tabular}

${ }^{a}$ The unit of BVOCs in Hong Kong is $\mathrm{Gg} \mathrm{C}$ per season.
ACPD

12, 6551-6592, 2012

\section{Estimation of BVOC emissions in China using MODIS data}

M. Li et al.

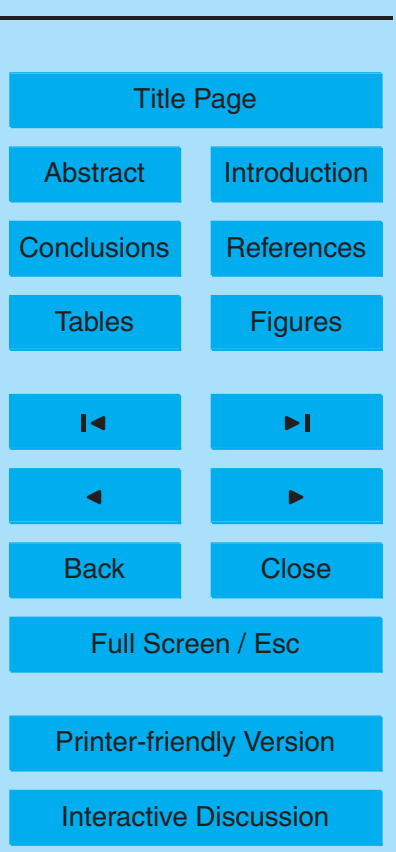


Table 4. Comparisons of the estimated BVOC budgets $\left(\mathrm{Tg} \mathrm{C} \mathrm{yr}^{-1}\right)$ and average emission fluxes (ton $\mathrm{C} \mathrm{km}^{-2} \mathrm{yr}^{-1}$ ) with previous studies.

\begin{tabular}{|c|c|c|c|c|c|c|}
\hline \multirow[t]{2}{*}{ Region } & \multirow[t]{2}{*}{ Area $\left(\times 10^{4} \mathrm{~km}^{2}\right)$} & \multicolumn{2}{|c|}{ Emission Budget } & \multicolumn{2}{|c|}{ Emission Flux } & \multirow[t]{2}{*}{ Reference } \\
\hline & & ISO & MT & ISO & MT & \\
\hline China & $928.9^{a}$ & 9.36 & 3.61 & 1.01 & 0.39 & This study \\
\hline China & $928.9^{\mathrm{a}}$ & 7.70 & 3.16 & 0.83 & 0.34 & Tie et al. (2006) \\
\hline China & $928.9^{\mathrm{a}}$ & 4.06 & 3.47 & 0.44 & 0.37 & Klinger et al. (2002) \\
\hline China & $928.9^{a}$ & 15.00 & 4.30 & 1.61 & 0.46 & Guenther et al. (1995) \\
\hline Beijing & $1.6^{\mathrm{a}}$ & 0.02 & 0.01 & 1.25 & 0.62 & This study \\
\hline Beijing & $1.78^{b}$ & 0.03 & 0.008 & 1.68 & 0.45 & Guenther et al. (1995) \\
\hline Beijing & $1.78^{b}$ & 0.014 & 0.008 & 0.79 & 0.45 & Klinger et al. (2002) \\
\hline Beijing & $1.78^{\mathrm{b}}$ & 0.008 & 0.004 & 0.45 & 0.22 & Wang et al. (2003) \\
\hline $\mathrm{PRD}^{\mathrm{c}}$ & $5.01^{a}$ & 0.12 & $6.90 \times 10^{-2}$ & 2.40 & 1.38 & This study \\
\hline PRD & $4.97^{d}$ & $9.54 \times 10^{-2}$ & $11.73 \times 10^{-2}$ & 1.92 & 2.36 & Wang et al. (2011) \\
\hline PRD & $4.70^{\mathrm{e}}$ & $6.40 \times 10^{-2}$ & $8.90 \times 10^{-2}$ & 1.36 & 1.89 & Zheng et al. (2010) \\
\hline Hong Kong & $0.1^{\mathrm{a}}$ & $0.78 \times 10^{-3}$ & $0.51 \times 10^{-3}$ & 0.78 & 0.51 & This study \\
\hline Hong Kong & $0.11^{f}$ & $0.26 \times 10^{-2}$ & $0.34 \times 10^{-2}$ & 2.36 & 3.09 & Tsui et al. (2009) \\
\hline Hong Kong & $0.11^{\mathrm{g}}$ & $0.69 \times 10^{-2}$ & $0.08 \times 10^{-2}$ & 6.27 & 0.72 & Leung et al. (2010) \\
\hline
\end{tabular}

a Land area of China and provinces were calculated using modeling grids in this study.

${ }^{\mathrm{b}}$ Land area of Beijing area was calculated using data provided by Klinger et al. (2002).

c PRD referred to the region located at the center of Guangdong Province in South China, including Guangzhou, Dongguan, Foshan, Shenzhen, Zhuhai, Zhongshan, Jiangmen, Huizhou and Zhaoging.

${ }^{d}$ Land area of PRD was calculated using data provided by Wang et al. (2011).

${ }^{e}$ Land area of PRD was calculated using $3 \mathrm{~km} \times 3 \mathrm{~km}$ grids in the study by Zheng et al. (2010).

${ }^{f}$ Land area of Hong Kong was calculated using data provided by Tsui et al. (2009).

${ }^{g}$ Land area of Hong Kong was calculated using data provided by Leung et al. (2010).
$12,6551-6592,2012$

\section{Estimation of BVOC emissions in China using MODIS data}

M. Li et al.

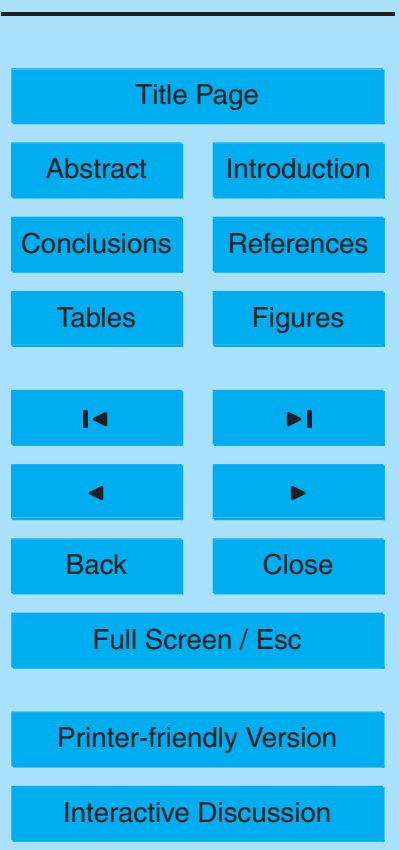




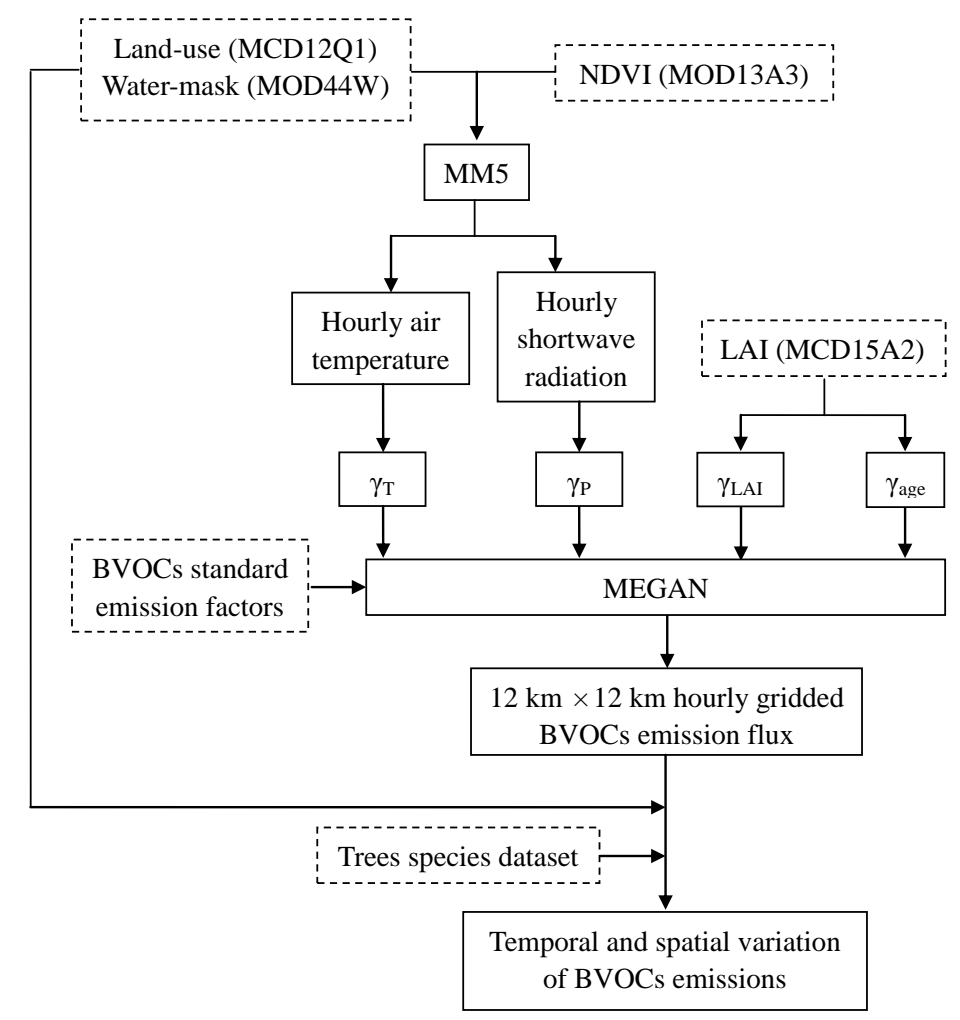

ACPD

12, 6551-6592, 2012

\section{Estimation of BVOC emissions in China using MODIS data}

M. Li et al.

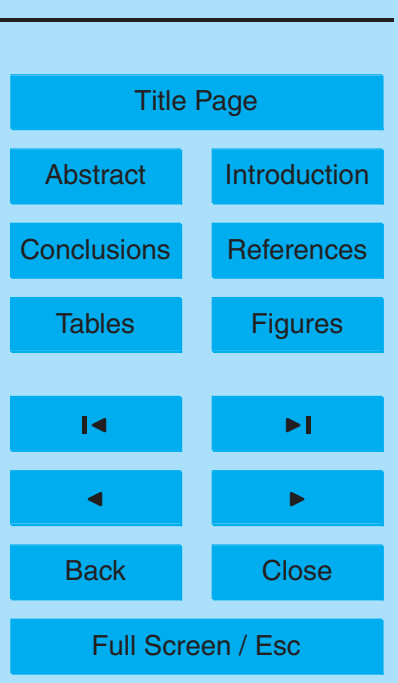

Fig. 1. Flowchart of the estimation of BVOC emissions, in which the dashed line box representing the model input.

Printer-friendly Version

Interactive Discussion 


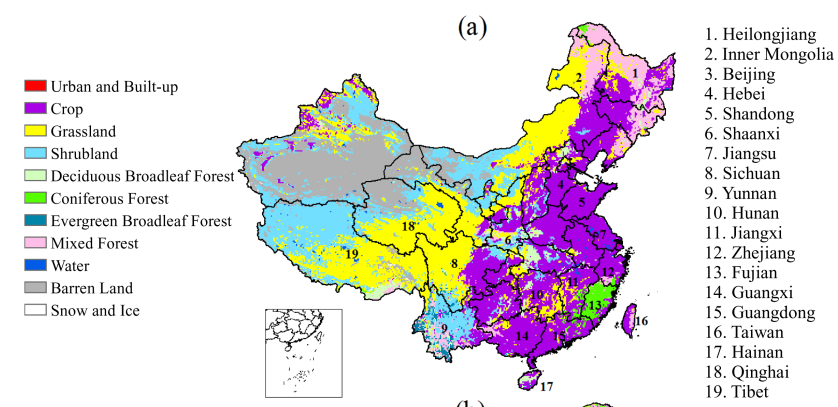

(b)

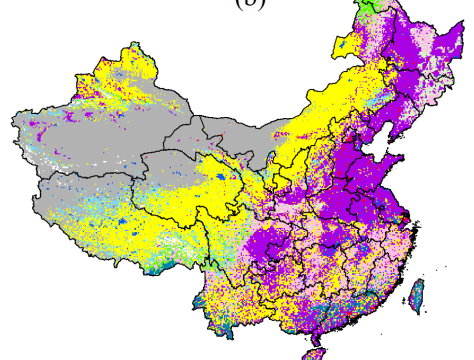

(c)

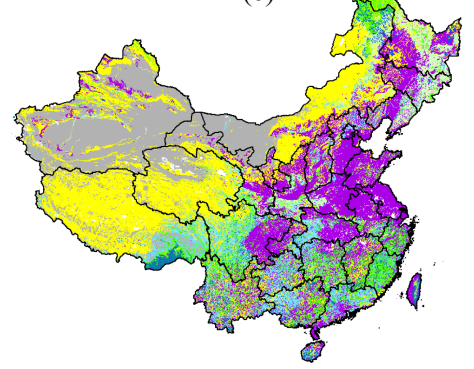

Fig. 2. Land-use maps for China derived from (a) the default USGS data; (b) MODIS observations; (c) tree species distribution data from the Plant Research Institute of the Chinese Academy of Sciences (to avoid confusion, the location of the Nansha Islands was not marked in the figures below).

\section{ACPD}

12, 6551-6592, 2012

\section{Estimation of BVOC emissions in China using MODIS data}

M. Li et al.

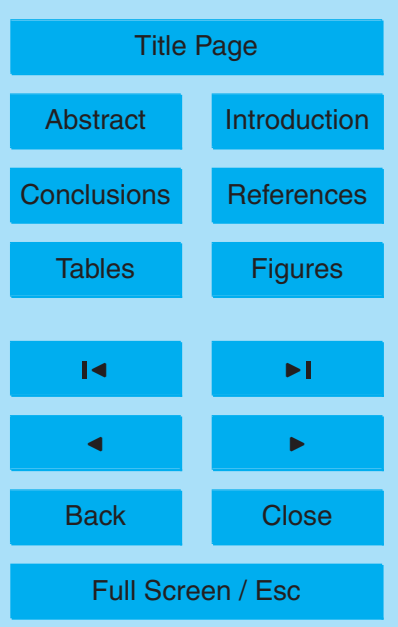

Printer-friendly Version

Interactive Discussion 
(a)

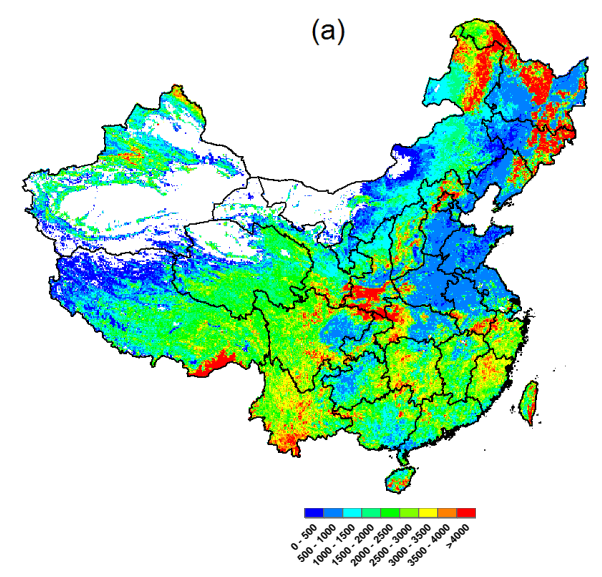

(b)

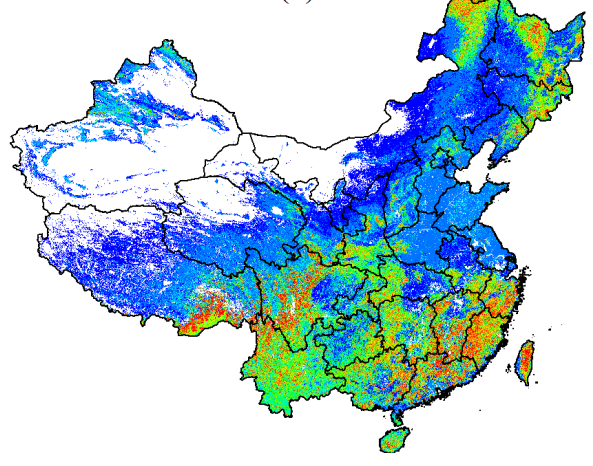

.

Fig. 3. Standard BVOC emission factors $\left(\mathrm{g} \mathrm{C} \mathrm{km}^{-2} \mathrm{~h}^{-1}\right)$ for China in 2000 based on $1 \mathrm{~km} \times 1 \mathrm{~km}$ grid; (a) isoprene; (b) monoterpenes.

ACPD

12, 6551-6592, 2012

\section{Estimation of BVOC emissions in China using MODIS data}

M. Li et al.

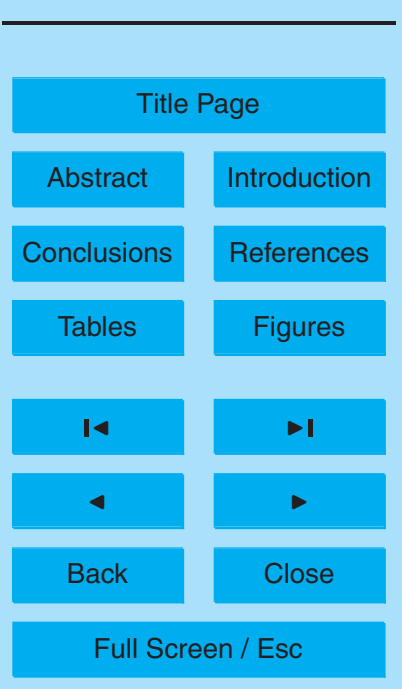

Printer-friendly Version

Interactive Discussion

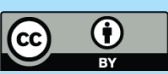


(a)

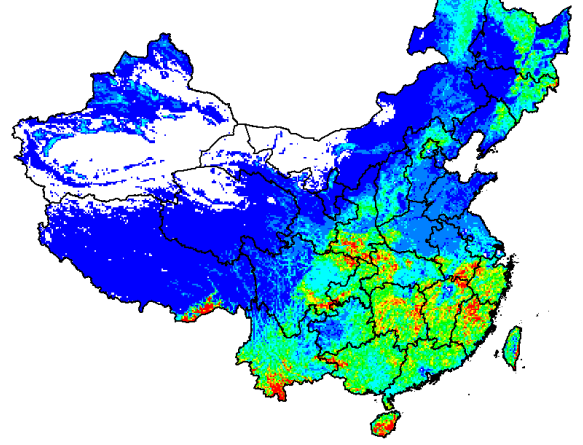

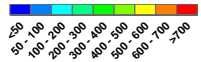

(b)

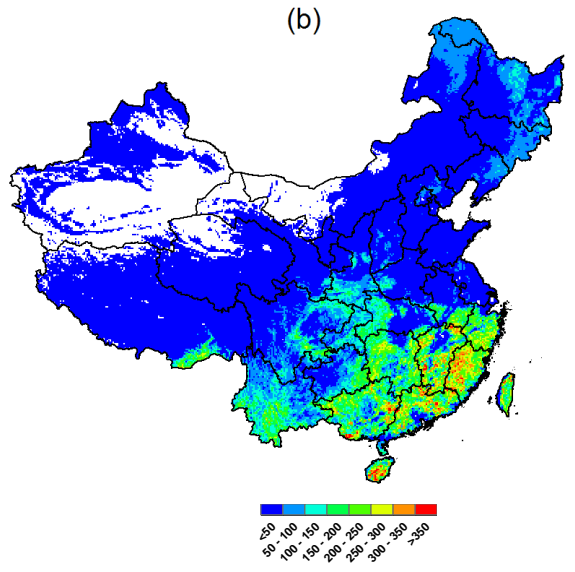

Fig. 4. Average (calculated) yearly biogenic emission fluxes of BVOCs $\left(\mathrm{g} \mathrm{C} \mathrm{km}^{-2} \mathrm{~h}^{-1}\right)$ for China in 2006: (a) isoprene; (b) monoterpenes.

\section{ACPD}

12, 6551-6592, 2012

\section{Estimation of BVOC emissions in China using MODIS data}

M. Li et al.

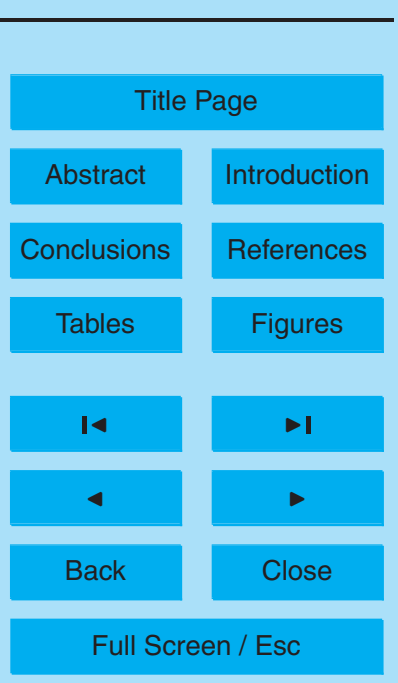

Printer-friendly Version

Interactive Discussion 

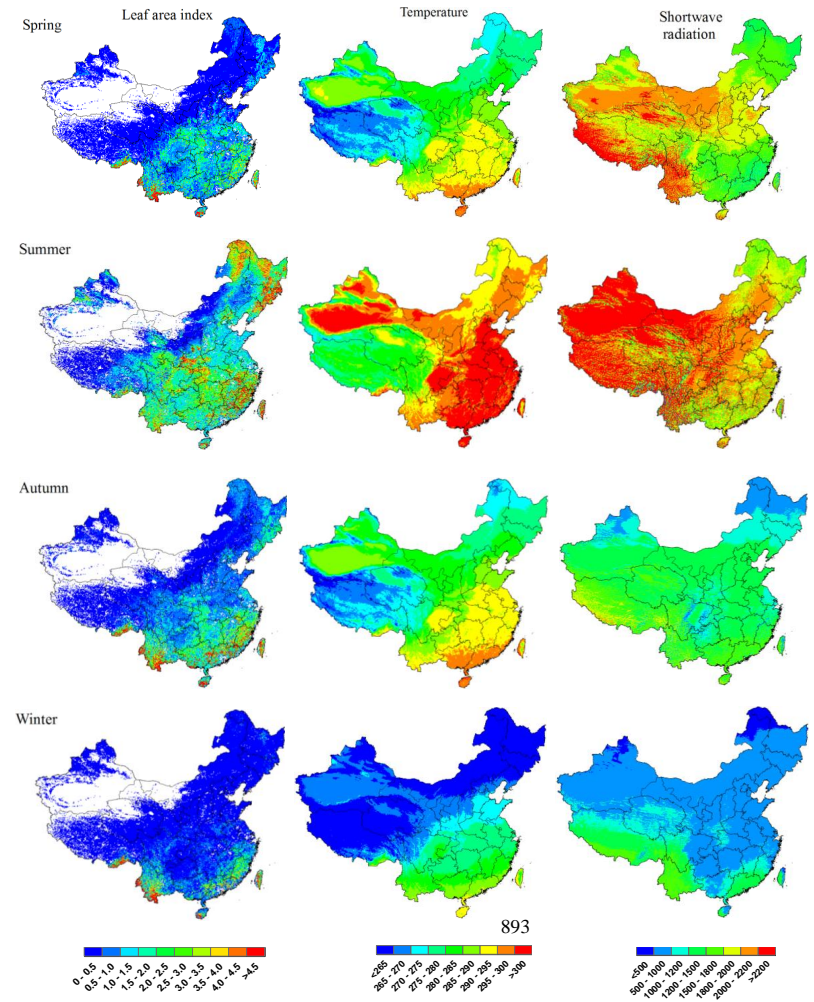

Fig. 5. Average (calculated) seasonal LAI values for China derived from MODIS data (left panel), simulated temperatures at $2 \mathrm{~m}(\mathrm{~K})$ (middle panel) and total solar shortwave radiation energy per season ( $\mathrm{MJ} \mathrm{m}^{-2}$ (right panel).

\section{ACPD}

$12,6551-6592,2012$

\section{Estimation of BVOC emissions in China using MODIS data}

M. Li et al.

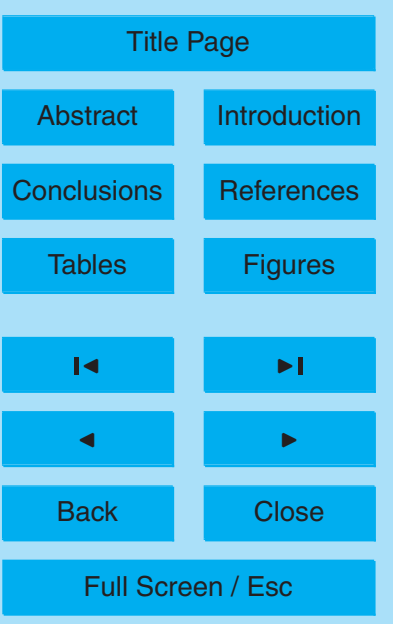

Printer-friendly Version

Interactive Discussion 


\section{ACPD}

12, 6551-6592, 2012
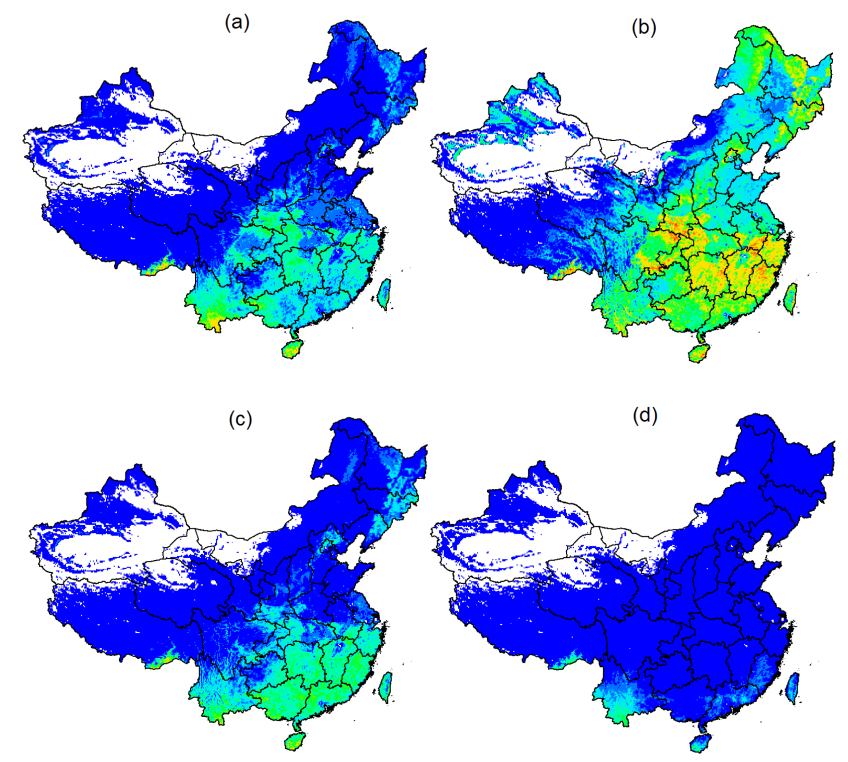

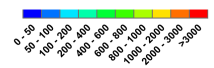

Fig. 6. Average (calculated) seasonal biogenic emission fluxes of isoprene $\left(\mathrm{g} \mathrm{C} \mathrm{km}^{-2} \mathrm{~h}^{-1}\right)$ : (a) spring; (b) summer; (c) autumn; (d) winter.

\section{Estimation of BVOC} emissions in China using MODIS data

\section{Li et al.}

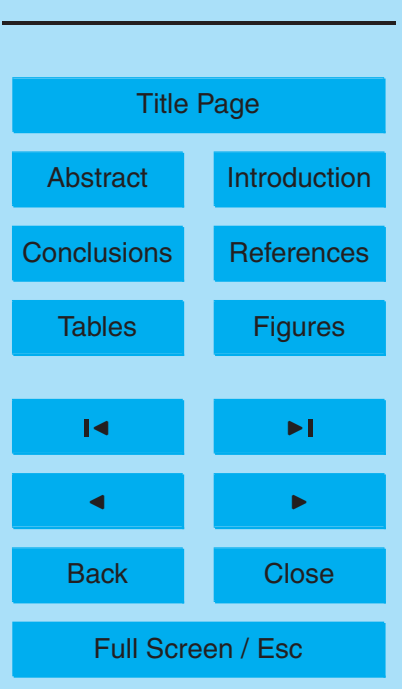

Printer-friendly Version

Interactive Discussion 


\section{ACPD}

12, 6551-6592, 2012
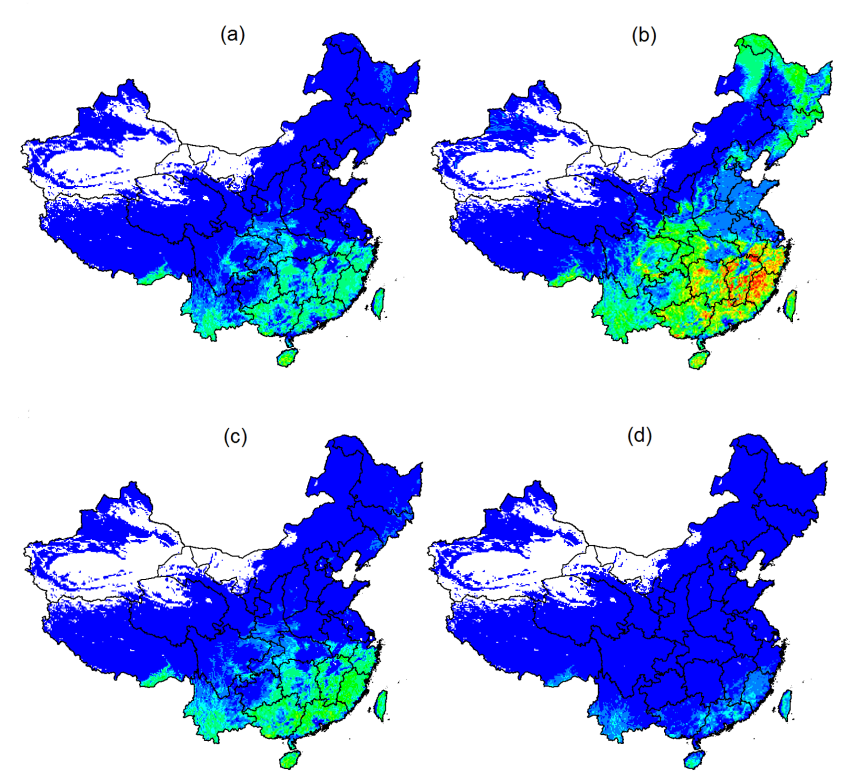

3

Fig. 7. Average (calculated) seasonal biogenic emission fluxes of monoterpenes ( $\mathrm{g} \mathrm{C} \mathrm{km}^{-2} \mathrm{~h}^{-1}$ ): (a) spring; (b) summer; (c) autumn; (d) winter.

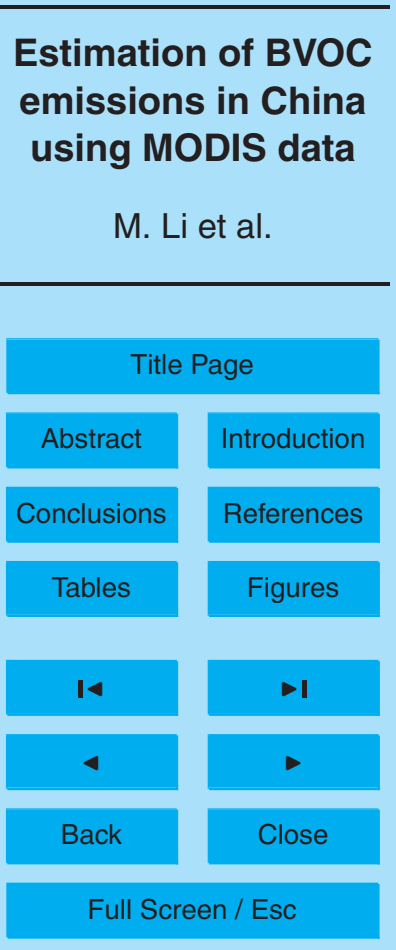

Printer-friendly Version

Interactive Discussion 


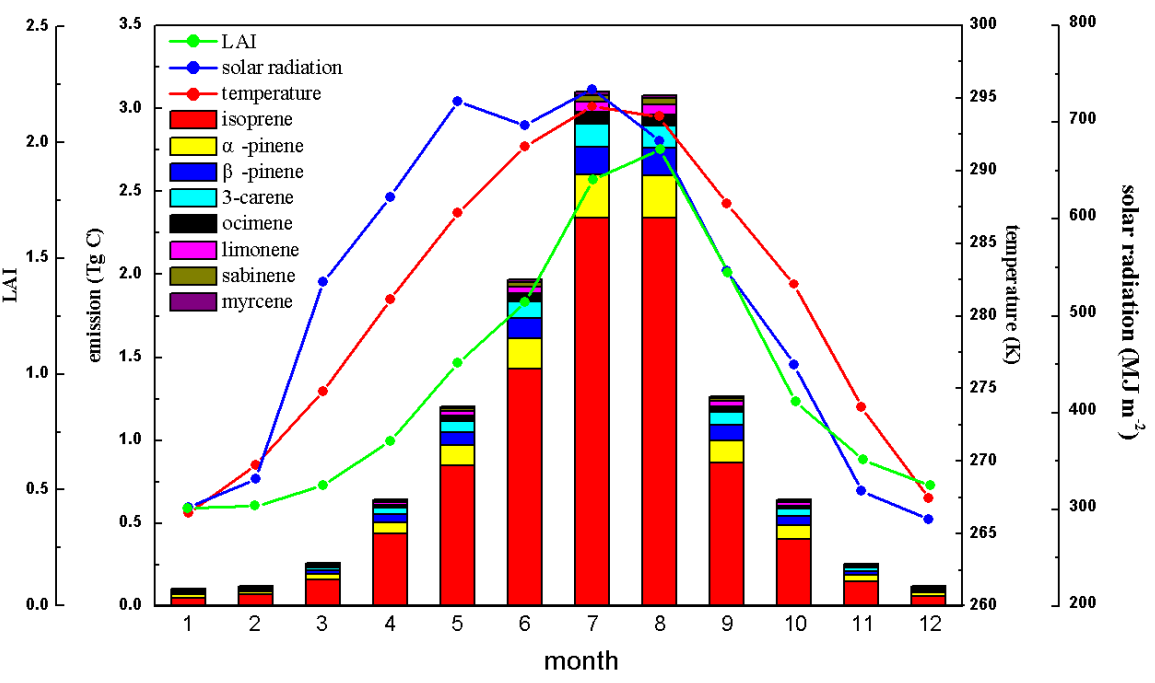

Fig. 8. Calculated monthly variation of biogenic emission rates of BVOCs, LAl values temperatures at $2 \mathrm{~m}$ and solar radiation energy.

\section{ACPD}

12, 6551-6592, 2012

\section{Estimation of BVOC emissions in China using MODIS data}

M. Li et al.

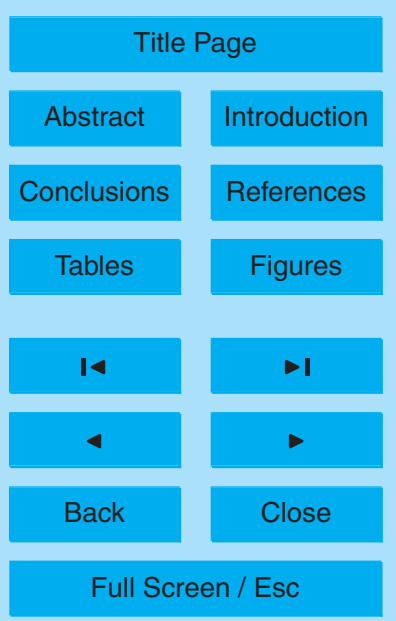

Printer-friendly Version

Interactive Discussion 